\title{
Manuring and stable nitrogen isotope ratios in cereals and pulses: towards a new archaeobotanical approach to the inference of land use and dietary practices
}

Rebecca A. Fraser ${ }^{1}$, Amy Bogaard ${ }^{1}$, Tim Heaton ${ }^{2}$, Michael Charles ${ }^{3}$, Glynis Jones ${ }^{3}$, Bent T. Christensen ${ }^{4}$, Paul Halstead ${ }^{3}$, Ines Merbach ${ }^{5}$, Paul R. Poulton ${ }^{6}$, Debbie Sparkes ${ }^{7}$ and Amy K. Styring $^{8}$

1. School of Archaeology, University of Oxford, 34-36 Beaumont Street, Oxford, United Kingdom OX1 2PG, United Kingdom.

Emails: Rebecca.fraser@arch.ox.ac.uk and Amy.bogaard@arch.ox.ac.uk

2. NERC Isotope Geosciences Laboratory, British Geological Survey, Keyworth, Nottingham NG12 5GG, United Kingdom.

Email: theh@bgs.ac.uk

3. Department of Archaeology, University of Sheffield,

Northgate House, West Street, Sheffield S1 4ET, United Kingdom.

Emails: M.P.Charles@Sheffield.ac.uk and g.jones@sheffield.ac.uk and

P.Halstead@sheffield.ac.uk

4. Department of Agroecology and Environment, Aarhus Universitet, Blichers Allé 20, P.O. BOX 50, DK-8830 Tjele, Denmark.

Email: Bent.T.Christensen@agrsci.dk

5. Versuchsstation Bad Lauchstädt, Helmholtz-Zentrum für Umweltforschung GmbH - UFZ, Hallesche Straße 44, 06246 Bad Lauchstädt, Germany.

Email: ines.merbach@ufz.de

6. Department of Sustainable Soils and Grassland Systems, Rothamsted Research, Rothamsted, Harpenden, Hertfordshire, AL5 2JQ, United Kingdom.

Email: paul.poulton@rothamsted.ac.uk

7. Division of Plant and Crop Sciences, School of Biosciences, University of Nottingham, Sutton Bonington Campus, Loughborough, Leicestershire, LE12 5RD, United Kingdom. Email: Debbie.sparkes@nottingham.ac.uk 
8. Organic Geochemistry Unit, Biogeochemistry Research Centre, School of

Chemistry, University of Bristol, Cantock’s Close, Bristol, BS8 1TS, United Kingdom.

Email: Amy.Styring@bristol.ac.uk

Corresponding author: Dr Rebecca Fraser, School of Archaeology, University of Oxford, 34-36 Beaumont Street, Oxford, United Kingdom OX1 2PG, United Kingdom.

Email: Rebecca.fraser@arch.ox.ac.uk. Phone: +44(0)1865 278147, Fax: +44(0)1865 278254.

Keywords: Nitrogen; Stable isotopes; Manuring; Neolithic; Crop husbandry; Palaeodiet

\begin{abstract}
This paper explores the impact of animal manure application on the $\delta^{15} \mathrm{~N}$ values of a broad range of crops (cereals and pulses), under a range of manuring levels/regimes and at a series of locations extending from northwest Europe to the eastern Mediterranean. We included both agricultural field experiments and areas where 'traditional' farming is practised. Our aim is to ground-truth interpretation of $\delta^{15} \mathrm{~N}$ values in archaeobotanical crop remains as evidence of past growing conditions and husbandry practices. The results confirm the potentially radical impact of manuring on $\delta^{15} \mathrm{~N}$ values in cereals, depending on manuring level, but indicate only a slight effect on pulses, which can fix atmospheric nitrogen. The expected geographical trend towards greater $\delta^{15} \mathrm{~N}$ with increasing climatic aridity is not apparent, probably because the growing conditions for crops are 'buffered' through crop management. Each of these observations has fundamental implications for archaeobotanical interpretation of $\delta^{15} \mathrm{~N}$ values as evidence of land use practices and (together with analysis of bone collagen/tooth enamel in potential consumers) palaeodiet.
\end{abstract}

\title{
1. Introduction
}

Human land use and cultivation practices for food and fodder production have altered the natural nitrogen $(\mathrm{N})$ cycle in many terrestrial ecosystems. Changes in stable nitrogen isotope ratios $\left({ }^{15} \mathrm{~N} /{ }^{14} \mathrm{~N}\right.$ ratios expressed as $\delta^{15} \mathrm{~N}$ values) in soils and plants have been used to trace anthropogenic influences on the $\mathrm{N}$ cycle at different temporal and spatial scales (Koerner et al. 1999; Robinson 2001; Templer et al. 2007; Watzka et al. 2006). One of the most influential effects on soil $\mathrm{N}$ dynamics within agricultural systems is the use of animal manure to improve overall soil fertility (Bol et al. 2008; Choi et al. 2006; Senbayram et al. 2008). This practice has been observed to result in an increase in the $\delta^{15} \mathrm{~N}$ value of soil, primarily 
due to bacterially-mediated reactions where the lighter ${ }^{14} \mathrm{~N}$ isotope is preferentially lost leading to ${ }^{15} \mathrm{~N}$ enrichment within the residual soil mineral $\mathrm{N}$ pools available to plants (Heaton 1986; Kendall et al. 2007; Kreitler and Jones 1975). Measures to improve soil conditions for crop production are important for understanding the development of agriculture. We seek to extend the use of natural abundance $\delta^{15} \mathrm{~N}$ studies to explore the nature of early farming by examining the isotopic composition of archaeobotanical remains.

Whilst a wide variety of natural environmental factors have been found to influence the $\delta^{15} \mathrm{~N}$ values of plants (climate, water stress, salinity and soil processes, particularly mineralization and denitrification), we concentrate here on the effect of fertilization with animal manure, which is associated with marked enrichment of ${ }^{15} \mathrm{~N}$ in soils and plants (Bol et al. 2005; Handley et al., 1999a, Heaton ,1987; Inglett et al., 2007; Yousfi et al., 2010). A recent pilot study (Bogaard et al. 2007) on the impact of manuring on modern cereal $\delta^{15} \mathrm{~N}$ values in two long-term agricultural experiments, one in the UK and the other in Germany, showed that manuring raised crop $\delta^{15} \mathrm{~N}$ values by 2.6 to $8.0 \%$, depending on intensity, compared to the unmanured fields at the same sites. Experimental charring as part of this study suggested further that manuring is potentially detectable through $\delta^{15} \mathrm{~N}$ values in charred archaeobotanical crop remains.

Direct identification of manuring practices from the remains of ancient crops would enhance the reliability and resolution of inferences on both land use practices and palaeodiet. With regard to manuring as part of land use, other archaeobotanical evidence is more ambiguous. Weed seeds associated with crops generally reflect overall growing conditions rather than manuring per se (e.g., Bogaard 2004: 142; Jones 2002) and their inclusion would complement the approach considered here by excluding other potential causes of $\delta^{15} \mathrm{~N}$ variability. Chemical and micromorphological analysis of rarely preserved palaeosols may indicate the deposition of manure but not necessarily the crops concerned or the intensity of manuring (Bull et al. 1999; Canti 1997; Evershed et al. 1997; Guttmann 2005; Simpson et al. 1999).

With regard to palaeodiet, the $\delta^{15} \mathrm{~N}$ values of soils and plants are passed on up though the food chain and recorded in the isotopic signatures of various soil invertebrates, herbivores and eventually human diets. Modern isotope studies observe increases in $\delta^{15} \mathrm{~N}$ values, of 
approximately 2 to 4\%, with each trophic step up the food chain (Ambrose 2000;

Schoeninger and DeNiro 1984). Hence, the $\delta^{15} \mathrm{~N}$ values in human and animal remains are central to the inference of trophic level in palaeodietary studies (Lee-Thorp 2008; Styring et al. 2010). A number of authors have noted that plant $\delta^{15} \mathrm{~N}$ values vary considerably, potentially complicating conventional interpretation of $\delta^{15} \mathrm{~N}$ values in faunal and human remains as reflecting the balance of animal- versus plant-derived foods in the diet (Dürrwächter et al. 2006; Hedges and Reynard 2007; Katzenberg 2000; van Klinken et al. 2000). If the animals and plants consumed by humans have similar $\delta^{15} \mathrm{~N}$ values, for example $+7 \%$, a problem of equifinality exists since it is impossible to distinguish a carnivorous or vegetarian diet from human values of approximately $+10 \%$. Information on $\delta^{15} \mathrm{~N}$ in plants is therefore essential for reliable interpretation and should ideally be evaluated alongside animal and human remains (e.g., Katzenberg 2000; van Klinken et al. 2000: 39-63). The evident impact of manuring on at least some food plants demonstrates that the interpretation of palaeodiet must be placed in a broader context of land use.

In this study we build on previous results in three ways: 1. by exploring the impact of animal manure application on $\delta^{15} \mathrm{~N}$ values in a broader spectrum of crops, both cereals and pulses; 2 . by considering a wider range of manuring levels; and 3. by encompassing study locations extending from northwest Europe to the eastern Mediterranean. The present study includes agricultural long-term experiments running for more than a century (Rothamsted, UK; Askov, Denmark; Bad Lauchstädt, Germany) and short-term experiments established as part of the project (at Sutton Bonington, UK and Tal Jebeen near Aleppo, Syria). Fields under 'traditional' farming regimes previously surveyed for their associated weed floras with a view to indirect archaeobotanical inference of crop husbandry practices were also included (Charles et al. 2002; Hajnalová et al. 2007; Jones et al. 1999, 2000). The aim was to facilitate interpretation of $\delta^{15} \mathrm{~N}$ values in archaeobotanical crop remains as evidence of land management and as a key part of palaeodietary investigations in Europe and southwest Asia. To this end, in addition to grains of cereals and seeds of pulses, we also analysed a further plant part identifiable to species and widely preserved in charred form: the rachis (central axis of the cereal ear), which in free-threshing cereals (such as bread wheat and barley) is separated from other chaff elements by threshing and in glume wheats (einkorn, emmer and spelt) retains the robust glumes. 
Whereas the previous study by Bogaard et al. (2007) considered only one cereal species (bread wheat, Triticum aestivum L.), the present study was designed to assess manuring impact on a range of cereal species and also on pulses. Pulses are harvested from leguminous plants which host bacteria capable of $\mathrm{N}_{2}$-fixation: the conversion of atmospheric $\mathrm{N}_{2}\left(\delta^{15} \mathrm{~N}=\right.$ $0 \%$ ) to ammonia. As the process involves very little isotopic fractionation, $\mathrm{N}_{2}$-fixing plants grown on soils with little plant-available $\mathrm{N}$ are provided with a source of $\mathrm{N}$ with a $\delta^{15} \mathrm{~N}$ value close to 0\%o (Marshall et al., 2007; Virginia and Delwiche, 1982). In contrast, non-fixing plants rely solely on sources of $\mathrm{N}$ for which $\delta^{15} \mathrm{~N}$ values are determined by a variety of isotope fractionating processes. The resulting $\delta^{15} \mathrm{~N}$ values for non-fixing plants are not easy to predict, though it is thought that climate (rainfall, temperature), salinity and cultivation history may all have an effect (Amundson et al., 2003; Aranibar et al., 2008; Broadbent et al., 1980; Handley et al., 1999; Heaton, 1987; Kriszan et al., 2009). The $\delta^{15} \mathrm{~N}$ values of cereals (non- $\mathrm{N}_{2}$-fixers) might be expected to show a more marked response to manuring than pulses (as $\mathrm{N}_{2}$-fixers), with responses differing in different locations. It was therefore important to consider pulses, alongside cereals, because they form a large part of archaeobotanical seedcrop assemblages and probably make up a sizable component of human and potentially also animal diets.

\section{Description of study sites}

Table 1 provides a summary of the land-use history, climate, crop types, soil conditions and manuring regimes applied in each of the field experiments. Descriptions of the farm study locations are summarised in Table 2. Classification of the manuring regimes applied in the farm studies is based on our field observations and discussions with farmers.

\subsection{Manuring at the long-term experimental sites}

In the long-term agricultural experiments at Rothamsted (United Kingdom), Askov (Denmark) and Bad Lauchstädt (Germany) a variety of cereal crops was grown on well established unmanured and manured plots for over a century. They provide a unique opportunity to examine the response of cereal $\delta^{15} \mathrm{~N}$ values to soil manuring and non-manuring at a range of time scales. At all sites cattle were the source of animal manure. The rate of manure applied was different at each station. At Rothamsted and Askov, one level of manure was applied; Rothamsted manured plots received approximately $35 \mathrm{t} / \mathrm{ha}$ of cattle farmyard 
manure (FYM 2) every year, while Askov manured plots (three replicates) received $37 \mathrm{t} / \mathrm{ha}$ of cattle slurry (SLU 1 1 12 ) as an annual average over the four course rotation. At Bad Lauchstädt there were two levels of manure applied to separate plots every other year: the first plot received approximately $20 \mathrm{t} / \mathrm{ha}$ (FYM 1), the second plot received approximately $30 \mathrm{t} / \mathrm{ha}$ (FYM 2).

At Rothamsted, samples were obtained from two 'classical' experiments — Broadbalk Winter Wheat and Hoosfield Spring Barley — both of which began in the mid 1800s (Rothamsted Research, 2006). In addition to long-term manured and unmanured plots, the Hoosfield Spring Barley experiment also provided samples from a treatment that was manured until 1871 and thereafter unmanured (FYMr). Broadbalk winter wheat grain and rachis $\delta^{15} \mathrm{~N}$ values, a time series from 1852 to 2004, are published in Bogaard et al. (2007). At Askov, winter-sown bread wheat (Triticum aestivum L.) and spring-sown hulled two-row barley (Hordeum vulgare var. distichum L.) form a normal part of the crop rotation and were sampled in 2007; for this study, spring-sown naked two-row barley (H. vulgare var. nudum), spelt wheat (Triticum spelta L.) and emmer wheat (Triticum dicoccum Schrank) were also grown in 2008. At Bad Lauchstädt, bread wheat was sampled in 2001, 2002, 2004 and 2007 and spring barley was sampled in 2007 and 2008; the data from 2001-2 and 2004 are published in Bogaard et al. (2007).

\subsection{Manuring at the short-term experimental sites}

Two short-term field experiments were established to study the effects of manuring levels on crop $\delta^{15} \mathrm{~N}$ values after only one year of manure application. At Sutton Bonington, United Kingdom, the experiments were established on organically managed land, at SB-Site A in 2007 and SB-Site B in 2008. These were adjacent fields of similar soil type. The land entered organic conversion in 1999 (receiving no agrochemicals, fertilisers or manure since that time), though the previous history is unknown. At SB-Site A (2007), einkorn (Triticum monococcum L.), emmer and spelt wheat were grown on unmanured and manured plots, the manured soil receiving $35 \mathrm{t} / \mathrm{ha}$ of cattle manure (FYM 2). At the adjacent SB-Site B (2008), the experiment was repeated, with added replication (4 replicate plots per manure treatment and grain type, with 3 replicates in 2007) and an additional 'intermediate' manure level of 15$20 \mathrm{t} / \mathrm{ha}$ (FYM 1). Both fields underwent the same rotation scheme (Table 1) and both were preceded by leys, which were cut and mulched to return organic matter to the soil. 
The second short-term field experiment was located $17 \mathrm{~km}$ north of Aleppo, Syria and established in a pistachio grove that had not received agrochemicals or manure in recent years. Bread wheat was grown without manure, with a 'medium' level (20 t/ha, FYM 1) and with a 'high' level (35 t/ha, FYM 2) of sheep manure. Irrigation was also incorporated in this experiment: all FYM 2 plots were also flood-irrigated six times during the growing season, while FYM 1 and unmanured plots were flood-irrigated either six or three times, or were not irrigated. The bread wheat experiment was repeated on different adjacent plots of land, ALSite A in 2008 and AL-Site B in 2009. Precipitation differed in these two years: 2008 was a 'drought' year, while 2009 rainfall was closer to the regional average (Table 1).

\subsection{Experimental pulses}

A variety of pulse types from long- and short-term experimental sites were included in the study. At Bad Lauchstädt in 2007 and 2008, peas (Pisum sativum L.) and broad beans (Vicia $f a b a$ L.) were grown in the same unmanured and manured plots as the cereals. In 2008 the pulses were grown in containers using soils from the fields to avoid rodents, which damaged the field-grown pulses the previous year. At Aleppo, lentils (Lens culinaris Medik.) were grown in separate plots under the same manure and irrigation treatments as the cereals. Lentil yields were low during 2008 due to low rainfall and, although pods formed, seed development was poor.

\subsection{Farm studies}

Three regions of 'traditional' farming - the Lena district of Asturias (Spain), the region east of Sighisoara in Transylvania (Romania) and the Aliveri district of Evvia (Greece) - were surveyed and sampled to assess the impact of manuring on $\delta^{15} \mathrm{~N}$ values in cereals and/or pulses in actual farm situations across different climatic zones (Figure 1, Table 2). In contrast with the field experiments, the farm manuring practices in a given year are likely to vary from one plot to the next, depending variously on proximity to animal stalling areas, the availability of manure (and thus the number and type of animals kept, degree of stallfeeding), means of transport and availability of human labour. With a view to archaeological interpretation of $\delta^{15} \mathrm{~N}$ crop values, the farm studies complement the field experiments by 
providing data on the isotopic variability to be expected among plots within a village community or cluster.

Within these areas, only arable fields with no recorded use of chemical fertilizers were sampled. In two of the regions, Asturias and Sighisoara, pulses growing together with cereals in the fields were also collected: broad beans and peas in Asturias, lentils in Sighisoara. In the third region, central Evvia, farmers practised 'pure' pulse cultivation, mostly of broad beans (Table 2). Manuring intensity varied within each region, from annual manuring, through biennial or triennial manuring (of potatoes or maize grown every two or three years in rotation with cereals/pulses) to lack of manuring in recent years or decades. In the Evvia study, contrasts in long-term manuring practice were accounted for by classifying cultivation plots as 'highly manured' if in close proximity to the farmers' houses and/or stalling areas or, in the case of plots relatively distant from habitation, with a history of use as vegetable gardens. Cattle manure was used in Asturias and Sighisoara, while the farmers in Evvia used sheep/goat dung. Manuring rates quantifiable as tonnes per hectare could not be established in the farm studies.

\section{Materials and methods}

To achieve an average representation of crop $\delta^{15} \mathrm{~N}$ values in each field or experimental plot, the following procedure was employed. First, 30 cereal or pulse plants were harvested along a central transect through each experimental plot or farm study field. Second, 10 cereal ears, or pulse pods, were randomly chosen from the group of 30 plants. The grains from one side of each of the 10 cereal ears, or half the contents of the pulse pods, were removed for final sampling; all of the rachis (with attached glumes, in the case of the glume wheats einkorn, emmer and spelt) from the 10 cereal ears was also taken for analysis. Therefore, each bulk sample represents a pooled sub-sample from 10 different plants from each plot or field (for cereals $\sim 200-300$ grains and for pulses $\sim 30-50$ seeds). For cereals, the grain and rachis in these sub-samples were separated from each other and analysed separately. All crop samples were ground to a fine homogeneous powder $(<250 \mu \mathrm{m}$ size $)$ under liquid nitrogen using a Spex 6850 freezer mill. 
$\mathrm{N}$ contents were determined in a Costech 4010 elemental analyser (Costech, Florence) with $\% \mathrm{~N}$ calculated by comparison with standards calibrated against acetanilide. ${ }^{15} \mathrm{~N} /{ }^{14} \mathrm{~N}$ analysis was performed by sample combustion in a Flash 112 elemental analyser (ThermoQuest, Milan) linked under continuous flow with a Delta+XL mass spectrometer (ThermoFinnigan, Bremen). Isotope ratios were calculated as $\delta^{15} \mathrm{~N}$ versus atmospheric $\mathrm{N}_{2}$ by comparison with standards calibrated against IAEA-N-1 (assumed $\delta^{15} \mathrm{~N}=+0.4 \%$ ) and $\mathrm{N}-2$ (assumed $\delta^{15} \mathrm{~N}=$ $+20.3 \%$ ), where:

$\delta^{15} N=\left(\frac{{ }^{15} N / 14 N_{\text {sample }}}{{ }^{15} N /{ }^{14} N_{\text {atmosN 2 }}}-1\right) \times 10^{3}$

The precision $(1 \sigma)$ among replicates of a homogenized barley sample was 0.2 for $\% \mathrm{~N}$ and $0.4 \%$ for $\delta^{15} \mathrm{~N}$ analysed in 29 separate runs.

Statistical analyses (using SPSS ${ }^{\text {TM }}$ PASW Statistics version 18) were undertaken on the short- and long-term experimental sites to test the significance of the manuring treatments on pulse, grain and rachis $\delta^{15} \mathrm{~N}$ and $\% \mathrm{~N}$ values. The combined effects of manuring and irrigation were also assessed for the Aleppo data. The following tests were applied: an independentsample t-test to the Rothamsted data, a two-way ANOVA with crop species and manure treatments as separate factors to the Sutton Bonington, Askov and Bad Lauchstädt data, and a two-way ANOVA with manure and irrigation levels as separate factors to the Aleppo data. For Bad Lauchstädt, sample sizes were too small for statistical analysis on separate years; therefore the data from all years were combined for pulses and cereals. A significance level of 0.05 was used for all statistical tests.

\section{Results}

\subsection{Cereals grown in long-term field experiments}

Tables 3a-c and Figure 2 summarise the results from the field experiments at Rothamsted (Broadbalk and Hoosfield), Bad Lauchstädt and Askov. Higher $\delta^{15} \mathrm{~N}$ values are associated with manured than with unmanured cereals in all three long-term experiments. These differences are visible across a range of species as well as in both grain and rachis. Overall, 
the average offset between farmyard manured and unmanured grain $\delta^{15} \mathrm{~N}$ values was $5.5 \%$ at Rothamsted and 4.0\%o at Bad Lauchstädt. At Askov with manured plots taking cattle slurry, the difference between unmanured and manured plots averaged 9.0\%. Grain $\delta^{15} \mathrm{~N}$ values are consistently higher than rachis $\delta^{15} \mathrm{~N}$ values, a relationship that is explored further below.

The earliest archive samples available at Rothamsted indicate that a pronounced 'manuring effect' becomes apparent within a decade of plot establishment: by 1856 in the Hoosfield spring barley experiment (which began in 1852) $\delta^{15} \mathrm{~N}$ values are already offset by $2.5 \%$, and by 1852 in the Broadbalk wheat experiment (which began in 1844) $\delta^{15} \mathrm{~N}$ values are offset by 3.1\%o. The Hoosfield Barley FYMr plot, which was manured from 1852 until 1871 (at the FYM2 level) only, records a gradual 3.5\% decline in crop $\delta^{15} \mathrm{~N}$ values once manuring stopped over a 70-year period (until 1942). Between 1942 and 1962 there is an increase in $\delta^{15} \mathrm{~N}$ values across all treatments, which may reflect changes in harvesting and/or weed control techniques (Poulton, pers com.) The span of the archive samples analysed from Rothamsted indicates further that, while there is inter-annual variation through time, manured and unmanured plot values remain distinct. An overall decrease in unmanured crop $\delta^{15} \mathrm{~N}$ values through time is evident in both the Hoosfield and Broadbalk experiments, resulting in greater offsets between manured and unmanured plots at the end of both time series $(7.6 \%$ and 5.8\%, respectively). Low crop $\delta^{15} \mathrm{~N}$ values in the unmanured plots probably reflect relatively small inputs of organic matter over the long term in comparison with the FYM plots.

While the results for bread wheat and hulled barley at Rothamsted, Bad Lauchstädt and Askov suggest similar manuring effects on both species, the additional data from Askov demonstrate that the effect of manuring is also similar for naked barley, emmer and spelt. The results indicate a remarkably consistent manuring effect across a broad range of cereals and confirm previous results from the Askov long-term experiments (Bol et al. 2005).

Different manuring levels have distinct impacts on the $\delta^{15} \mathrm{~N}$ values in cereals. At Bad Lauchstädt the higher of two manure application levels, FYM 2 (30t/ha biennially), is associated with $\sim 1.5 \%$ higher crop $\delta^{15} \mathrm{~N}$ values than FYM 1 (20 t/ha biennially). More intensive manuring practices at Rothamsted (35 t/ha annually) and Askov (37 t/ha, annually) are associated with even higher $\delta^{15} \mathrm{~N}$ values. The highest manured cereal $\delta^{15} \mathrm{~N}$ values occur at Askov $(8.5 \% \pm 0.3)$, where the use of cattle slurry with a relatively high ammonium content 
(rather than farmyard manure with a larger fraction of the manure $\mathrm{N}$ in organic forms) may be a factor.

\subsection{Cereals grown in short-term experiments}

The manured and unmanured plots of einkorn, emmer and spelt wheat grown at Sutton Bonington provide data on cereal $\delta^{15} \mathrm{~N}$ values in the first cultivation season after cattle manure application. The results, summarised in Table 4a and Figure 3, demonstrate an appreciable but variable 'manuring effect' across the three cereal types in the two years. Unmanured plot $\delta^{15} \mathrm{~N}$ values at SB-Site A in 2007 are markedly higher than those at SB-Site $\mathrm{B}$ in 2008. The degree of $\delta^{15} \mathrm{~N}$ enrichment in the FYM 2 plots compared with unmanured plots also differs between the two years, with increases in 2007 averaging $2.6 \pm 0.8 \%$ o versus an average difference of $1.0 \pm 0.4 \%$ in 2008 . The magnitude of the manuring effect in this first year of manure application at Sutton Bonington is lower than that observed in the longterm experimental fields but comparable to the earliest archive samples at Rothamsted, when unmanured values were still relatively high. Overall, the Sutton Bonington results suggest that: 1) the degree of manuring impact on cereal $\delta^{15} \mathrm{~N}$ values can vary between sites and years; 2) the difference between manured and unmanured plots in the first season after initial application is smaller than the difference after long-term cultivation with/without manure; and 3) there are no obvious differences in manuring effect amongst the three hulled wheat species.

At Aleppo, Syria, where manuring was combined with irrigation, analysis of bread wheat grown at AL-Site A in 2008 on newly established plots registered a low-level 'manuring effect' of 1.9\%o (Table 4b, Figure 3). In 2009 at AL-Site B, however, $\delta^{15} \mathrm{~N}$ values of bread wheat grown on newly established plots, immediately adjacent to those cultivated in the previous year, exhibited a much more dramatic manuring impact, particularly where manuring was combined with full irrigation, resulting in an average offset of 3.5\%. These different offsets may be related to the marked contrast in annual rainfall received between 2007 and 2008; even though irrigation levels were the same for each year, rainfall was approximately $60 \mathrm{~mm}$ higher in 2009 (see Table 1). Overall, the Syrian results suggest that the effect of manuring on cereal $\delta^{15} \mathrm{~N}$ may also be dependent on water availability, whether derived from precipitation or from irrigation. 
Combined with the analysis of early archive samples from Rothamsted (above), the results of the short-term experiments suggest that significant ${ }^{15} \mathrm{~N}$ enrichment can emerge in the first cultivation season following initiation of intensive manuring, but much depends on sitespecific conditions and, particularly in arid regions, on water availability.

\subsection{Experimentally grown pulses}

The $\delta^{15} \mathrm{~N}$ values of pulses grown at Bad Lauchstädt, under the same manured and unmanured soils as those for the cereals (including field- and container-grown pulses), are shown in Table $3 \mathrm{c}$ and are plotted in Figure 4. The results show only small or no enrichment of $\delta^{15} \mathrm{~N}$ values (mean $+0.2 \%$ ) at the FYM1 level of manuring and a slightly larger effect (mean $+0.7 \%$ ) at the highest FYM2 level of manuring. Given that the pulses were grown in cereal plots in 2007 but in pots in 2008, it is unlikely that root competition with cereals, which have more extensive rooting systems than pulses, can explain the low pulse values.

At Aleppo, Syria, lentils grown in 2008 and 2009 on newly established plots also showed only a slight tendency (mean $+0.3 \%$ ) towards ${ }^{15} \mathrm{~N}$ enrichment at the FYM1 level of manuring (both irrigated and non-irrigated). The higher FYM2 manured plots (here, combined with high irrigation) showed a larger response (mean $+0.8 \%$ ) to manuring (Table $4 \mathrm{~b}$, Figure. 4 ). Yield data collected as part of the experiment in 2008 showed that the yield of manured lentil plots was greater (averaging $212 \mathrm{~kg}$ seed weight/dunum), than that of unmanured lentil plots (averaging $174 \mathrm{~kg} /$ dunum), therefore confirming that manuring was indeed beneficial despite its low impact on $\delta^{15} \mathrm{~N}$ values.

Overall, the low $\delta^{15} \mathrm{~N}$ values of the manured pulses compared to the manured cereals indicate that they are still heavily affected by fixation of atmospheric nitrogen, even when they are intensively manured at the levels applied in the experimental studies (i.e. range of 20 to 35 $\mathrm{t} /$ ha). Any tendency towards ${ }^{15} \mathrm{~N}$ enrichment of pulses associated with low manure levels (here, $<$ FYM1, 15-20t/ha) maybe too slight to distinguish from overall analytical measurement precision (here, $\pm 0.4 \%$ ) . 


\subsection{Farm studies}

Tables 5a-b and Figure 5 summarise the results from the farm studies. As in the datasets from the long- and short-term experiments, rachis values are consistently lower than grain values (see also below). Enrichment of cereal $\delta^{15} \mathrm{~N}$ values is evident amongst manured soils but is also variable. This variation is attributable at least in part to manuring intensity and/or history; for example, the highest spelt $\delta^{15} \mathrm{~N}$ value from Asturias (10.1\%o) derived from an unusual plot in which the farmer had manured the spelt very intensively, "like potatoes".

Comparison of the two studies featuring combined cereal and pulse cultivation (Asturias and Sighisoara) shows that, in both cases, pulses always have lower values than cereals growing in the same plots. This observation is consistent with the ability of pulses to make greater use of fixed atmospheric N. While it could be argued that the deeper rooting systems of cereals in comparison with pulses enables them to compete successfully for mineral soil $\mathrm{N}$, as noted above pulses grown experimentally in pots also show relatively low $\delta^{15} \mathrm{~N}$ values.

The highest $\delta^{15} \mathrm{~N}$ values of any pulses measured in the project derive from the third farming region, central Evvia, Greece (Table 5c, Figure 5). Farmers here manured some pulse plots very intensively, resulting in the formation of an artificial 'dung-soil' (koprókhoma). On average, highly manured pulses have higher $\delta^{15} \mathrm{~N}$ values than those grown on plots receiving low or infrequent manure application (Table 5c).

\subsection{Results of statistical analyses and the relationships between $\delta^{15} \mathrm{~N}$ and $\% \mathrm{~N}$ in grain and rachis}

The results of the statistical analyses conducted on separate sites and crop species are summarised in Tables 6 and 7. Overall, the effect of the manure treatments on experimental cereal grain $\delta^{15} \mathrm{~N}$ values is highly significant $(\mathrm{p}<0.01)$ for all sites with the exception of Sutton Bonington Site-B in $2008(\mathrm{p}=0.313)$. Cereal grain $\delta^{15} \mathrm{~N}$ values at Aleppo showed a larger response to manuring than to irrigation. The effect of irrigation on cereal grain $\delta^{15} \mathrm{~N}$ values at Aleppo was only significant in 2009 (note also the higher level of rainfall that year).

There was a significant effect of FYM2 manuring on lentil $\delta^{15} \mathrm{~N}$ values at Aleppo in both years; yet no significant effects were evident for irrigation. In contrast, manuring had no significant effect on pulse $\delta^{15} \mathrm{~N}$ values at Bad Lauchstädt in either year sampled, yet the 
significant effect of species $(\mathrm{p}<0.05)$ indicates that peas and broad beans responded slightly differently to manure application; peas had $\delta^{15} \mathrm{~N}$ values on average $0.3 \%$ higher (see Figure 4a) than broad beans. In light of these results, a two-way was ANOVA conducted on the sites where pulses and cereals were grown together (Aleppo and Bad Lauchstädt), which included crop type (i.e. cereal or pulse) and manure treatment as factors. The main effects of crop type and manuring on $\delta^{15} \mathrm{~N}$ values were both significant (Bad Lauchstädt: crop type $F(2,10)=153.2, \mathrm{p} \leq .000$ and manure $F(2,10)=36.9, \mathrm{p} \leq .000$. ; Aleppo: crop type $F(2,107)=45.5, \mathrm{p} \leq .000$ and manure $F(2,107)=20.3, \mathrm{p} \leq .000)$. Furthermore, there was a significant interaction between crop type and manure treatment (Bad Lauchstädt: $F(2,10)=20.7, p \leq .000$. Aleppo: $\mathrm{F}(2,107)=11.1, p \leq .000)$, which statistically confirms overall that the pulses and cereals responded differently to the manure treatments.

Manuring had much less of an effect on grain $\% \mathrm{~N}$ values than on $\delta^{15} \mathrm{~N}$ values; the only significant effect of manure treatment (FYM 2) on \%N was observed in Askov crops in 2007 (unmanured M (mean) =1.2, SD 0.0, FYM 2 M=1.4, SD 0.2, p<0.05). During 2007, there was also a small, yet only just significant, effect of cereal species on $\% \mathrm{~N}$ at Askov $(\mathrm{p}=0.04)$, where hulled two-row barley had marginally higher $\% \mathrm{~N}$ than bread wheat $(\mathrm{M}=1.3, \mathrm{SD} 0.1$, and $\mathrm{M}=1.5$, SE 0.1 , respectively). A significant effect of cereal species on $\% \mathrm{~N}$ was also observed at Sutton Bonington SB-Site A in 2007, where spelt had lower \%N (M=1.8, $\mathrm{SD}=0.2)$ than emmer and einkorn wheat $(\mathrm{M}=2.1, \mathrm{SD}=0.3$ and $\mathrm{M}=2.5, \mathrm{SD}=0.3$, respectively).

Statistical analysis of the cereal rachis $\delta^{15} \mathrm{~N}$ and $\% \mathrm{~N}$ values (Table 7) produced very similar results to that of the cereal grain. The main difference is that manuring had no significant impact on rachis $\delta^{15} \mathrm{~N}$ values at Aleppo AL-Site B in 2009.

The study observed that cereal rachis $\delta^{15} \mathrm{~N}$ values were consistently lower than cereal grain $\delta^{15} \mathrm{~N}$ values across all of the study sites, and this relationship is shown in Figure 6. The mean offset between grain and rachis was $2.4 \pm 0.8 \%$ (Pearson product-moment correlation coefficient: $r=0.962, n=179, \mathrm{P}<0.001)$. Nevertheless, rachis $\delta^{15} \mathrm{~N}$ values show the same magnitude of manuring effect as cereal grain. Rachis also had lower $\% \mathrm{~N}$ values than cereal grains and pulses: mean $\% \mathrm{~N}$ was $0.3 \% \pm 0.2$ for all rachis samples, $1.6 \% \pm 0.3$ for all cereal grain samples and $3.9 \% \pm 0.2$ for all pulse samples. 


\section{Geographical variation}

The experimental sites in this study were spread across a wide geographic area with a range of markedly different climatic conditions and soil types (see Table 1 and Figure 1). Previous studies have observed that relatively warm, dry climates are associated with higher plant $\delta^{15} \mathrm{~N}$ values than cooler and wetter temperate ones (e.g. Amundson et al. 2003; Aranibar et al. 2004; Handley et al. 1999a; Heaton 1987). In order to investigate this specific plant/climate association in relation to our crop study, Pearson product-moment correlation coefficients were computed to assess relationships between experimental cereal $\delta^{15} \mathrm{~N}$ values (unmanured and FYM 2) and site-specific mean annual precipitation (MAP). There was no significant correlation between unmanured cereal $\delta^{15} \mathrm{~N}$ values and MAP, $\mathrm{r}=-0.304, \mathrm{n}=13, \mathrm{p}=0.313$. However, there was a significant positive correlation between FYM 2 manured cereal $\delta^{15} \mathrm{~N}$ values and MAP, $r=0.984, n=13, p=0.000$. Scatter plots summarize these results (see Figure $7 \mathrm{a}$ and $7 \mathrm{~b}$ ). It therefore appears that generalized geographical trends towards ${ }^{15} \mathrm{~N}$ enrichment with decreasing rainfall are not apparent in the unmanured cereals sampled in this project, and that the opposite trend-towards higher $\delta^{15} \mathrm{~N}$ values with increasing rainfall—is evident among the intensively manured FYM2 treatments. In considering these geographical patterns, however, it may not be realistic to compare broad global trends of entire ecosystems (Amundson et al., 2003; Handley et al., 1999a) with the restricted range of agricultural conditions under which our crops were grown. In addition it must be accepted that the relationship between plant $\delta^{15} \mathrm{~N}$ values and water availability is a complex issue, with conflicting results (both positive and negative relationships) from different studies (Amundson et al. 2003; Lopes and Araus, 2006; Yousfi et al., 2010). Moreover, the positive FYM2 vs. MAP trend (Figure 7b) could be more apparent than real when duration of the manure regimes are considered: low values at Aleppo may reflect long-term cultivation without manuring prior to establishing the short-term experiment (only one year of manure application so far); the FYM2 treatment at Bad-Lauchstädt is applied biennially; and lower values at Sutton Bonington than at Rothamsted may reflect the short-term nature (also only one year of manure application so far) of intensive manuring at the former.

\section{Discussion}

The experimental results synthesized here suggest clear causal links between cereal $\delta^{15} \mathrm{~N}$ values and the intensity and longevity of cultivation with and without manuring. Contrasting 
levels and frequencies of application amongst the long-term experiments (Table 3) are reflected in differing offsets between manured and unmanured treatments (Figure 2). Though subtle variation in manuring impact on different cereal species cannot be excluded, it is clear that different cereal species grown under the same conditions have similar values.

The long-term field experiments suggest that a baseline range of $\delta^{15} \mathrm{~N}$ values can be established to interpret archaeobotanical cereal $\delta^{15} \mathrm{~N}$ values (see Figure 2). The time-series available from the Rothamsted archives, as well as Askov and Bad Lauchstädt, indicate that cereals grown without manuring over the long term are low in ${ }^{15} \mathrm{~N}$, resulting in values below $\sim 2.5 \%$. By contrast, long-term continued cultivation of cereals with high levels of annual manuring ( 35-37 t/ha, applied annually), as at Rothamsted and Askov, results in high values of $\sim 6 \%$ or higher.

Medium values between $\sim 2.5 \%$ and $\sim 6 \%$ o could reflect several scenarios: lower levels of manure application over the long-term (as in the biennial application of $\sim 20-30$ tons/a at Bad Lauchstädt); the residual effects after a period of intensive manuring (as in the FYMr plot at Rothamsted), or the early years of a new cultivation regime (as in the early archive samples at Rothamsted). The latter scenario could be excluded archaeobotanically if associated arable weed assemblages suggest long established cultivation plots (Bogaard 2002). ). Applying these baselines archaeologically would require not only complementary information from available weed evidence but also relevant palaeoecological contextualisation with regard to other possible causes of ${ }^{15} \mathrm{~N}$ enrichment (e.g. wetland denitrification, salinity etc.).

While long-term manuring practices are sufficiently marked that they might be discernible archaeologically, the results of the short-term field experiments suggest that crops grown after an initial season of intensive manure input will not necessarily register a marked effect on $\delta^{15} \mathrm{~N}$ values. Though these results limit the resolution of land-use inferences as regards short-term manuring, they also suggest that $\operatorname{crop} \delta^{15} \mathrm{~N}$ values indicative of high manuring levels reflect long-term continuity, with consequent implications for the stability of land tenure. The 'slow-release' nature of manuring effects on soils (DEFRA, 2010) suggests that the practice lends itself to long-term investment in arable land.

The results presented also confirm previous indications based on pilot work (Bogaard et al. 2007) of a systematic offset between cereal grain and rachis. This consistent result (Figure 6) 
has significant implications both for the interpretation of archaeobotanical grain versus chaff values and also for palaeodietary work, where the values of plants consumed by humans and other animals are often assumed to be similar. If cereal grain were mostly consumed by humans and rachis/glumes by animals, it is evident that the offset between these plant sources would approximate the trophic level effect. Work on other plant parts suggests that straw, leaves and other structural plant parts are similarly low in $\delta^{15} \mathrm{~N}$ relative to grain (Smolinska unpublished data 1991 cited in Bogaard et al. 2007). The offset in $\delta^{15} \mathrm{~N}$ values between grain and other plant parts suggests that it may be possible to distinguish between animal foddering with chaff and with grain, which have markedly different implications for both animal productivity and cost to the farmer.

The effect of manuring on pulses is comparatively slight, possibly due to the pervasive impact of atmospheric $\mathrm{N}_{2}$-fixation, especially when grown on soils with very little mineral $\mathrm{N}$ (ammonium and nitrate) availability. In one study, Evvia in Greece, where broad beans and other pulses were in some cases treated with extremely high levels of manuring over an extended period, certain manured pulse values were significantly offset from unmanured values (Figure 5c). It is likely that the highly manured soils in Evvia have abundant mineral $\mathrm{N}$, which results in pulses taking up mineral soil $\mathrm{N}$ and reducing their $\mathrm{N}_{2}$-fixing activity, and thereby achieving $\delta^{15} \mathrm{~N}$ values that overlap with the signatures of manured cereal values observed in other farming studies. The implication is that very intensive manuring of pulses would be detectable archaeobotanically, whereas lower levels would not. In palaeodietary terms, it appears that pulses would generally contribute low $\delta^{15} \mathrm{~N}$ values $(\leq 2.5 \%)$, unless treated with extremely high levels of manure.

Finally, the comparison of experimental and 'real' farming studies is important for framing potential interpretation of archaeobotanical $\operatorname{crop} \delta^{15} \mathrm{~N}$ values. The farm studies register considerable variation amongst plots forming part of the same general manuring regime. This apparent variability in actual manuring level probably reflects a combination of factors, including scarcity of manure, resulting in selective use, as well as variation amongst farming families in available time/labour for spreading manure.

The observation that fairly consistent values for cereals and pulses occur across the studies is significant for archaeological inferences on both land use and palaeodiet. For land use reconstruction, it appears that manuring has similar enrichment effects in different climate 
zones and soil types. The finding that the unmanured cereal grain $\delta^{15} \mathrm{~N}$ values observed in this study do not follow the commonly observed negative relationship with local mean annual rainfall (Figure 7a) indicates that climatic conditions, here represented by a single meteorological variable such as rainfall, are not the dominant determining factor. Cereal $\delta^{15} \mathrm{~N}$ values, especially at the long-term experimental sites, are predominately responding to the application of high levels of manure and soils with a readily available source of ${ }^{15} \mathrm{~N}$ enriched mineral $\mathrm{N}$, more so than to precipitation or soil moisture balance levels in isolation. Longterm intensive manuring of arable soils increases the overall $\mathrm{N}$ content and microbial action, which leads to greater decomposition and mineralization of organic $\mathrm{N}$ and further increases the likelihood of conditions that result in ${ }^{14} \mathrm{~N}$ losses, mobilised either by volatilisation or leaching. These losses may increase with rainfall/water availability thus enhancing the manuring effect (Figure $7 \mathrm{~b}$ ), but the lack of long-term intensive annual manuring in medium to low-level rainfall areas amongst our sites restricts our ability to explore this relationship. Nevertheless, it seems clear that crop $\delta^{15} \mathrm{~N}$ values in this study derive from a range of artificially 'buffered' growing conditions and do not reflect the plant/climate trends observed in natural habitats elsewhere (e.g., Amundson et al. 2003; Heaton 1987).

In terms of palaeodiet, interpreting high $\delta^{15} \mathrm{~N}$ values in crops as indicative of aridity would be problematic given the lack of correlation between unmanured cereal $\delta^{15} \mathrm{~N}$ and rainfall and the observed 'enriching' effects that land use practices like manuring can have on crop $\delta^{15} \mathrm{~N}$ values in a range of high and low-rainfall areas. Although the effects of aridity on a broad range of plant $\delta^{15} \mathrm{~N}$ values are observed at a variety of local and global scales (e.g., Handley et al. 1999b; Hartman and Danin 2009; Heaton 1987; Schwarcz et al. 1999), this study suggests that other explanations for elevated $\delta^{15} \mathrm{~N}$ values in human or animal consumers should be considered. For palaeodiet interpretations, this inference would ideally be assessed directly through isotopic analysis of archaeobotanical remains.

\section{Conclusion}

Our data suggest that long-term cultivation with or without manuring can result in radically different cereal $\delta^{15} \mathrm{~N}$ values; middling values are associated with the early years of a manuring regime or with moderate manure levels. Moreover, $\delta^{15} \mathrm{~N}$ values in different cereal plant parts (specifically, grain and rachis) differ systematically. Unless very intensive over an extended period, the impact of manuring on $\delta^{15} \mathrm{~N}$ values in pulses is slight or lacking 
altogether. Measurement of $\delta^{15} \mathrm{~N}$ values in archaeobotanical remains is desirable both as direct evidence of crop growing conditions and crop husbandry practices and as a central component of palaeodietary investigations.

\section{Acknowledgements}

The work reported here was funded by the Natural Environment Research Council (NERC standard grant NE/E003761/1, PI Bogaard), supplemented by the John Fell Oxford University Press Research Fund, which made possible a second year of experimental crop growing near Aleppo. We are grateful to George Arab and Ken Street for facilitating the Syrian experimental trials and to Maria Hajnalová and Noémi Pažinová for their guidance in Romania. The Danish contribution was financially supported by Carlsberg Fondet. We thank the Lawes Trust for access to the archived Rothamsted samples. Rothamsted Research is an institute of the Biotechnology and Biological Sciences Research Council in the UK. Additional thanks go to Andy Macdonald and Marie Kanstrup for assistance with sampling and processing of the Hoosfield Barley material and to Chris Kendrick for $\% \mathrm{~N}$ determinations on the elemental analyser.

\section{References}

Ambrose, S.H. (2000) Controlled diet and climate experiments on nitrogen isotope ratios of rat bone collagen, hair and muscle. In S.H. Ambrose and M.A. Katzenberg (eds.) Biogeochemical Approaches to Paleodietary Analysis. Kluwer Academic/Plenum, New York, pp. 243-259.

Amundson, R., Austin, A.T., Schuur, E.A.G., Yoo, K., Matzek, V., Kendall, C., Uebersax, A., Brenner, D. and Baisden, W.T. (2003). Global patterns of the isotopic composition of soil and plant nitrogen. Global Biogeochemical Cycles, 17, article no. 1031.

Aranibar, J.N., Otter, L., Macko, S.A., Feral, C.J.W., Epstein, H.E., Dowty, P.R., Eckardt, F., Shugart, H. H. and Swap, R. J. (2004) Nitrogen cycling in the soil-plant system along a precipitation gradient in the Kalahari sands. Global Change Biology, 10: 359-373. 
Aranibar, J.N., Anderson, I.C., Epstein, H.E., Feral, C.J.W. and Swap, R.J., Ramontsho, J. and Macko, S.A. (2008) Nitrogen isotope composition of soils, $\mathrm{C}_{3}$ and $\mathrm{C}_{4}$ plants along land use gradients in southern Africa, Journal of Arid Environments, 72: 326-337.

Bogaard, A. (2002) Questioning the relevance of shifting cultivation to Neolithic farming in the loess belt of Europe: evidence from the Hambach Forest experiment. Vegetation History and Archaeobotany, 11: 155-168.

Bogaard, A. (2004). Neolithic Farming in Central Europe. London, Routledge.

Bogaard A, Heaton, T.H.E., Poulton, P. and Merbach, I. (2007) The impact of manuring on nitrogen isotope ratios in cereals: archaeological implications for reconstruction of diet and crop management practices. Journal of Archaeological Science, 34: 335-343.

Bol, R., J. Eriksen, P. Smith, M.H. Garnett, K. Coleman, B.T. Christensen (2005) The natural abundance of ${ }^{13} \mathrm{C},{ }^{15} \mathrm{~N},{ }^{34} \mathrm{~S}$ and ${ }^{14} \mathrm{C}$ in archived (1923-2000) plant and soil samples from the Askov long-term experiments on animal manure and mineral fertilizer. Rapid Communications in Mass Spectrometry, 19: 3216-3226.

Bol, R., Ostle, N. J., Petzke, K. J., Chenu, C., Balesdent, J. (2008) Amino acid ${ }^{15} \mathrm{~N}$ in longterm bare fallow soils: influence of annual $\mathrm{N}$ fertilizer and manure applications. European Journal of Soil Science, 59 (4): 617-625.

Broadbent, F.E., Rauschkolb, R.S., Lewis, K.A. and Chang, G.Y., 1980. Spatial variability in nitrogen-15 and total nitrogen in some virgin and cultivated soils. Soil Science Society of America Journal, 44: 524-527.

Bull, I.D., Simpson, I.A., Van Bergen, P.F. and Evershed, R.P. (1999) Muck 'n' molecules: organic geochemical methods for detecting ancient manuring, Antiquity, 73: 86-96.

Canti,M.G. (1997) An investigation of microscopic calcareous spherulites from herbivore dungs, Journal of Archaeological Science, 24: 219-231.

Charles, M., Bogaard, A., Jones, G., Hodgson, J. and Halstead, P. (2002) Ecological investigation of intensive cereal cultivation in the mountains of Asturias, NW Spain. Vegetation History and Archaeobotany, 11: 133-142. 
Choi, W.J., Arshad, M.A., Chang, S.X., Kim, T.H. (2006) Grain ${ }^{15} \mathrm{~N}$ of crops applied with organic and chemical fertilizers in a four-year rotation. Plant and Soil, 284:165-174.

Christensen, B. T., J. Petersen, and U. M. Trentemøller. 2006. The Askov Long-Term Experiments on Animal Manure and Mineral Fertilizers: The Lermarken site 1894-2004. DIAS report Plant production 121. Tjele: Danish Institute of Agricultural Sciences.

Defra (2010) Fertiliser Manual (RB209). Department of the Environment, Food and Rural Affairs, The Stationary Office, London.

Dürrwächter, C., Craig, O. E., Collins, M.J., Burger, J. and Alt, K. W. (2006) Beyond the grave: variability in Neolithic diets in Southern Germany? Journal of Archaeological Science, 33: 39-48.

Evershed, R.P., Bethell, P.H., Reynolds, P.J. and Walsh, N.J. (1997) 5ß-Stigmastanol and related 5ß-Stanols as biomarkers of manuring: analysis of modern experimental material and assessment of the archaeological potential. Journal of Archaeological Science, 24: 485-495.

Guttman, E.B.A. (2005) Midden cultivation in prehistoric Britain: arable crops in gardens, World Archaeology, 37: 224-239.

Hajnalová, M., Eliáš, P. and Pažinová, N. (2007) Floristic composition of Triticum monococcum fields in Transylvania (Romania): preliminary results. In: Brindza, J. (ed.), Traditional Agroecosystems '05, 11th International Conference and Satellite Workshops. Nitra: Slovak University of Agriculture, pp. 127-131.

Handley, L., Austin, A.T., Robinson, D., Scimgeour, C.M., Raven, J.A., Heaton, T.H.E, Schmidt, C. and Stewart, D.R. (1999a) The ${ }^{15} \mathrm{~N}$ natural abundance $\left(\delta^{15} \mathrm{~N}\right)$ of ecosystem samples reflects measures of water availability. Australian Journal of Plant Physiology, 26: 185-199,

Handley, L.L., Azcon, R., Lozano, J.M.R. and Scrimgeour, C.M. (1999b) Plant delta N-15 associated with arbuscular mycorrhization, drought and nitrogen deficiency. Rapid Communications in Mass Spectrometry, 13: 1320-1324. 
Hartman, G. and Danin, A. (2009) Isotopic values of plants in relation to water availability in the Eastern Mediterranean region. Oecologia, 162: 837-852,

Heaton, T.H.E. (1986). Isotopic studies of nitrogen pollution in the hydrosphere and atmosphere: a review. Chemical Geology, 59: 87-102.

Heaton, T.H.E. (1987) The ${ }^{15} \mathrm{~N} /{ }^{14} \mathrm{~N}$ ratios of plants in South Africa and Nambia: Relationship to climate and coastal/saline environments. Oecologia, 74: 236-246.

Hedges, R.E.M. and Reynard, L.M. (2007) Nitrogen isotopes and the trophic level of humans in archaeology. Journal of Archaeological Science, 34: 1240-1251.

Inglett, P.W., Reddy, K.R., Newman, S. and Lorenzen, B. (2007). Increased soil stable nitrogen isotopic ratio following phosphorus enrichment: historical patterns and tests of two hypotheses in a phosphorus-limited wetland. Oecologia, 153: 99-109.

Jones, G. (2002) Weed ecology as a method for the archaeobotanical recognition of crop husbandry practices. Acta Palaeobotanica, 42: 185-193.

Jones, G., Bogaard, A., Halstead, P., Charles, M. and Smith, H. (1999) Identifying the intensity of crop husbandry practices on the basis of weed floras. Annals of the British School at Athens, 94: 167-189.

Jones, G., Bogaard, A., Charles, M. and Hodgson, J.G. (2000) Distinguishing the effects of agricultural practices relating to fertility and disturbance: a functional ecological approach in archaeobotany. Journal of Archaeological Science, 27: 1073-1084.

Katzenberg, M.A. (2000) Stable Isotope Analysis: A Tool for Studying Past Diet, Demography, and Life History. In: Katzenberg MA, Saunders SR (eds) Biological Anthropology of the Human Skeleton. Wiley-Liss, Inc., Canada, pp. 305-327.

Kendall, C., Elliott, E.M. and Wankel, S.D. (2007) Tracing anthropogenic inputs of nitrogen to ecosystems. In: R. Michener and K. Lajtha (eds.) Stable Isotopes in Ecology and Environmental Science, Blackwell Publishing, pp. 375-449. 
Koerner, W., Dambrine, E., Dupouey, J.L. and Benoit, M. (1999) Delta N-15 of forest soil and understorey vegetation reflect the former agricultural land use. Oecologia, 121: 421-425.

Körschens, M. and Pfefferkorn, A. (1998) Bad Lauchstädt - The Static Fertilization Experiment and other Long-term Field Experiments. UFZ-Umweltforschungszentrum Leipzig-Halle GmbH.

Kreitler, C.W. and Jones, D.C. (1975) Natural soil nitrate: the cause of the nitrate contamination of groundwater in Runnels County, Texas. Ground Water, 13, 53-61.

Kriszan, M., Amelung, W., Schellberg, J., Gebbing, T. and Kühbauch, W. (2009). Long-term changes of the $\delta^{15} \mathrm{~N}$ natural abundance of plants and soil in a temperate grassland. Plant and Soil, 325: 157-169.

Lee-Thorp, J.A. (2008) On isotopes and old bones, Archaeometry, 50: 925-950.

Lopes, M. and Aruas, J.L. (2006) Nitrogen source and water regime effects on durum wheat photosynthesis, and stable carbon and nitrogen isotope composition. Physiologia Plantarum, 126: 435-445.

Marshall, J.D., Brooks, J.R. and Lajtha, K. (2007) Sources of variation in the stable isotopic composition of plants. In: R. Michener and K. Lajtha (editors) Stable Isotopes in Ecology and Environmental Science, Blackwell Publishing, pp.22-60.

Robinson, D. (2001) $\delta^{15} \mathrm{~N}$ as an integrator of the nitrogen cycle. Trends in Ecology \& Evolution, 16: 153-162.

Rothamsted Research (2006) Guide to the Classical and other Long-term Experiments, Datasets and Sample Archive. Lawes Agricultural Trust Co. Ltd, Harpenden, UK

Schoeninger, M.J. and DeNiro, M.J. (1984) Nitrogen and carbon isotopic composition of bone collagen from marine and terrestrial animals. Geochimica et Cosmochimica Acta, 48: 625-639.

Schwarcz, H.P., Dupras, T. and Fairgrieve, S. (1999) ${ }^{15}$ N Enrichment in the Sahara: In Search 
of a Global Relationship. Journal of Archaeological Science, 26: 629-636.

Senbayram, M., Dixon, L., Goulding, K.W.T. and Bol, R. (2008) Long-term influence of manure and mineral nitrogen applications on plant and soil $\delta^{15} \mathrm{~N}$ and $\delta^{13} \mathrm{C}$ values from the Broadbalk Wheat Experiment. Rapid Communications in Mass Spectrometry, 22: 1735-1740.

Simpson, I.A., Bol, R., Bull, I.D., Evershed, R.P., Petzke, K.J. and Dockrill, S.J. (1999) Interpreting early land management through compound specific stable isotope analyses of archaeological soils, Rapid Communications in Mass Spectrometry, 13: 1315-1319.

Styring,A.K., Sealy, J.C. and Evershed, R.P. (2010) Resolving the bulk $\delta^{15} \mathrm{~N}$ values of ancient human and animal bone collagen via compound-specific nitrogen isotope analysis of constituent amino acids, Geochimica et Cosmochimica Acta, 74(1): 241-251.

Templer, P., Arthur, M., Lovett, G. and Weathers, K. (2007) Plant and soil natural abundance $\delta^{15} \mathrm{~N}$ : indicators of relative rates of nitrogen cycling in temperate forest ecosystems.

Oecologia, 153: 399-406.

van Klinken, G.J., Richards, M.P. and Hedges, R.E.M. (2000) An overview of causes for stable isotope variations in past European human populations: environmental ecophysiological and cultural effects. In: Ambrose SH, Katzenberg MA (eds.) Biogeochemical Approaches to Palaeodietary Analysis. Kluwer Academic, New York, pp. $39-63$.

Virginia, R.A. and Delwiche, C.C. (1982) Natural ${ }^{15} \mathrm{~N}$ abundance of presumed N2-fixing and non-N2-fixing plants from selected ecosystems. Oecologia, 54: 317-325.

Watzka, M., Buchgraber, K. and Wanek, W. (2006) Natural ${ }^{15} \mathrm{~N}$ abundance of plants and soils under different management practices in a montane grassland. Soil Biology and Biochemistry, 38: 1564-1576.

Yousfi, S., Serret, M.D., Voltas, J. and Araus, J.L. (2010). Effect of salinity and water stress during the reproductive stage on growth, ion concentrations, $\Delta^{13} \mathrm{C}$, and $\delta^{15} \mathrm{~N}$ of durum wheat and related amphiploids, Journal of Experimental Botany, 61: 3529-3542. 
Table 1

Summary of the experimental field sites

Table 2

Summary of the farming study locations

Table 3a

Results for the analysis of bulk samples from, Rothamsted, UK, A) Hoosfield Barley Experiment, and B) Broadbalk Winter Wheat Experiment (data from Bogaard et al., 2007 are included for comparison): Nil = unmanured; FYM2=35t/ha manure; FYMrmanured from 1852 until 1871and unmanured thereafter; na = material not available for analysis (no replicate plots per treatment).

Table $3 b$

Results for the analysis of bulk samples from Askov, Denmark: Nil = unmanured plot; SLU $1 \frac{1}{2}=35 \mathrm{t} /$ ha manure slurry (average of three replicate plots per treatment, with 1 SD in parentheses).

Table 3c

Results for the analysis of bulk samples from Bad Lauchstädt, Germany: Nil = unmanured plot; FYM1 = 20t/ha manure; FYM2 = 35t/ha manure; na = material not available for analysis (no replicate plots per treatment).

Table $4 \mathrm{a}$

Results for the analysis of bulk samples from Sutton Bonington, United Kingdom: Nil = unmanured plot; FYM 1 = 15-20t/ha manure; FYM 2 = 35t/ha manure; na= not available (average of three replicate plots per treatment, with 1 SD in parentheses). 
Table $4 b$

Results for the analysis of bulk samples from Aleppo, Syria: Nil-a = no manure/no irrigation, Nil-b = no manure/medium irrigation; Nil-c = no manure/full irrigation; FYM $1 \mathrm{a}=$ medium (20t/ha) manure/no irrigation; FYM1-b = medium (20t/ha) manure/medium irrigation; FYM1-c = medium (20t/ha) manure/full irrigation; FYM2 = high (35t/ha) manure/full irrigation (average of three replicate plots per treatment, with 1 SD in parentheses).

Table 5a

Results for the analysis of bulk samples from the Lena district, central Asturias, Spain: $\mathrm{Na}=$ material not available for analysis; nd $=$ not determined; Not Recent $=$ no recent manure applied; Biennial = manure applied every second year; Direct $=$ manure applied during sampled growing season (an average of 3 to 4 replicate fields were sampled per manure level (when available), with 1 SD in parentheses)

Table $5 b$

Results for the analysis of bulk samples from the Sighisoara region, Transylvania, Romania: $n a=$ material not available for analysis; $\mathrm{nd}=$ not determined; Not recent $=$ no recent manure applied; Triennial = manure applied every third year; Direct $=$ manure applied during sampled growing season (an average of 3 to 4 replicate fields were sampled per manure level (when available), with 1 SD in parentheses).

Table 5c

Results for the analysis of bulk samples from the Aliveri district of central Evvia, Greece: Low = low manure, High= high manure (an average of 3 to 4 replicate fields were sampled per manure level (when available), with 1 SD in parentheses). 
Table 6

Results of two-way ANOVA tests (t-test applied to Rothamsted) on cereal grain and pulse, A) $\delta^{15} \mathrm{~N}$ values and, B) \%N values ( $\mathrm{F}$ (df effect, $\mathrm{df}$ error $)=\mathrm{F}$ value, $\mathrm{p}$-value. $\dagger$ indicates data from all years were combined because sample sizes were too small for statistical analysis on separate years, na $=$ not applicable, ${ }^{*}$ significant response at an alpha level of 0.05).

Table 7

Results of two-way ANOVA tests (t-test applied to Rothamsted) on cereal rachis, A) $\delta 15 \mathrm{~N}$ values and, $\mathrm{B}) \% \mathrm{~N}$ values $(\mathrm{F}(\mathrm{df}$ effect, $\mathrm{df}$ error $)=\mathrm{F}$ value, $\mathrm{p}$-value. $\dagger$ indicates data from all years were combined because sample sizes were too small for statistical analysis on separate years, na $=$ not applicable, ${ }^{*}$ significant response at an alpha level of 0.05). 
Table 1

Summary of the experimental field sites

\begin{tabular}{|c|c|c|c|c|c|c|c|c|c|c|}
\hline Experiment & Location & Period & $\begin{array}{l}\text { Climate } \\
\text { (Köppen- } \\
\text { Geiger) }\end{array}$ & Soil type & $\begin{array}{l}\text { Annual } \\
\text { rainfall } \\
(\mathrm{mm})\end{array}$ & Cropping regime & Crop(s) sampled & $\begin{array}{l}\text { Manuring } \\
\text { treatment(s) }\end{array}$ & $\begin{array}{l}\text { Plot(s) } \\
\text { sampled }\end{array}$ & References \\
\hline \multicolumn{11}{|l|}{ Long-term: } \\
\hline $\begin{array}{l}\text { Broadbalk Winter } \\
\text { Wheat, Rothamsted }\end{array}$ & $\begin{array}{l}\text { Hertfordshire, } \\
\text { United Kingdom }\end{array}$ & $\begin{array}{l}\text { 1844- } \\
\text { present }\end{array}$ & $\begin{array}{l}\text { Temperate } \\
\text { oceanic }\end{array}$ & $\begin{array}{l}\text { Chromic luvisol; } \\
\text { flinty-silty clay } \\
\text { loam over Clay- } \\
\text { with-flints }\end{array}$ & 727 & $\begin{array}{l}\text { Autumn-sown bread } \\
\text { wheat }\end{array}$ & Triticum aestivum & $\begin{array}{l}\text { Cattle manure, } \\
35 \text { tonnes/ha } \\
\text { every year }\end{array}$ & $\begin{array}{l}\text { Single plot per } \\
\text { treatment }\end{array}$ & $\begin{array}{l}\text { Rothamsted } \\
\text { Research } \\
2006\end{array}$ \\
\hline $\begin{array}{l}\text { Hoosfield Spring } \\
\text { Barley, Rothamsted }\end{array}$ & $\begin{array}{l}\text { Hertfordshire, } \\
\text { United Kingdom }\end{array}$ & $\begin{array}{l}1852- \\
\text { present }\end{array}$ & $\begin{array}{l}\text { Temperate } \\
\text { oceanic }\end{array}$ & $\begin{array}{l}\text { Chromic luvisol; } \\
\text { flinty-silty clay } \\
\text { loam over Clay- } \\
\text { with-flints }\end{array}$ & 727 & $\begin{array}{l}\text { Spring-sown hulled two- } \\
\text { row barley }\end{array}$ & $\begin{array}{l}\text { Hordeum vulgare var. } \\
\text { Distichum }\end{array}$ & $\begin{array}{l}\text { Cattle manure, } \\
35 \text { tonnes/ha } \\
\text { every year }\end{array}$ & $\begin{array}{l}\text { Single plot per } \\
\text { treatment }\end{array}$ & $\begin{array}{l}\text { Rothamsted } \\
\text { Research } \\
2006\end{array}$ \\
\hline $\begin{array}{l}\text { Askov Long-Term } \\
\text { Experiment }\end{array}$ & $\begin{array}{l}\text { South Jutland, } \\
\text { Denmark }\end{array}$ & $\begin{array}{l}\text { 1894- } \\
\text { present }\end{array}$ & $\begin{array}{l}\text { Temperate } \\
\text { oceanic/cool } \\
\text { temperate }\end{array}$ & $\begin{array}{l}\text { Alfisol (Typical } \\
\text { Hapludalf); coarse } \\
\text { sandy loam }\end{array}$ & 862 & $\begin{array}{l}\text { Autumn-sown bread } \\
\text { wheat/root crops/spring } \\
\text { hulled two-row } \\
\text { barley/clover and grass } \\
\text { (4-course rotation) }\end{array}$ & $\begin{array}{l}\text { Triticum aestivum; } \\
\text { Hordeum vulgare var. } \\
\text { distichum; Triticum } \\
\text { dicoccum; Triticum } \\
\text { spelta; Hordeum vulgare } \\
\text { var. } \text { nudum* }^{*}\end{array}$ & $\begin{array}{l}\text { Cattle slurry, } c \text {. } \\
37 \text { tonnes/ha } \\
\text { (mean across } \\
\text { rotation) }\end{array}$ & $\begin{array}{l}\text { Three replicate } \\
\text { plots per } \\
\text { treatment }\end{array}$ & $\begin{array}{l}\text { Christensen } \\
\text { et al. } 2006\end{array}$ \\
\hline $\begin{array}{l}\text { Static Fertilization } \\
\text { Experiment, Bad } \\
\text { Lauchstädt }\end{array}$ & $\begin{array}{l}\text { Leipzig-Halle, } \\
\text { Germany }\end{array}$ & $\begin{array}{l}\text { 1902- } \\
\text { present }\end{array}$ & $\begin{array}{l}\text { Cool } \\
\text { temperate }\end{array}$ & $\begin{array}{l}\text { Haplic } \\
\text { chernozem; loess }\end{array}$ & 483 & $\begin{array}{l}\text { Autumn-sown bread } \\
\text { wheat/sugar beet/spring- } \\
\text { sown hulled two-row } \\
\text { barley/potatoes (4-course } \\
\text { rotation) }\end{array}$ & $\begin{array}{l}\text { Triticum aestivum; } \\
\text { Hordeum vulgare var. } \\
\text { distichum; Lens } \\
\text { culinaris; Pisum } \\
\text { sativum; Vicia faba** }\end{array}$ & $\begin{array}{l}\text { Cattle manure, } \\
20 \text { and } 30 \\
\text { tonnes } / \text { ha } \\
\text { every second } \\
\text { year }\end{array}$ & $\begin{array}{l}\text { Single plot per } \\
\text { treatment }\end{array}$ & $\begin{array}{l}\text { Körschens } \\
\text { and } \\
\text { Pfefferkorn } \\
1998\end{array}$ \\
\hline \multicolumn{11}{|l|}{ Short-term: } \\
\hline Sutton Bonington & $\begin{array}{l}\text { Nottinghamshire, } \\
\text { United Kingdom }\end{array}$ & $2007-8$ & $\begin{array}{l}\text { Temperate } \\
\text { oceanic }\end{array}$ & $\begin{array}{l}\text { Stagnogleic } \\
\text { argillic brown } \\
\text { earth }\end{array}$ & 606 & $\begin{array}{l}\text { Autumn-sown einkorn, } \\
\text { emmer and spelt } \\
\text { wheat/winter } \\
\text { beans/winter oat/clover } \\
\text { or vetch and ryegrass (4- } \\
\text { course rotation) }\end{array}$ & $\begin{array}{l}\text { Triticum monococcum; } \\
\text { Triticum dicoccum; } \\
\text { Triticum spelta }\end{array}$ & $\begin{array}{l}\text { Cattle manure, } \\
35 \text { tonnes/ha, } \\
\text { plus } \\
\text { intermediate } \\
\text { level of } 15-20 \\
\text { tonnes/ha in } \\
2008\end{array}$ & $\begin{array}{l}\text { Four replicate } \\
\text { plots per } \\
\text { treatment, } \\
\text { randomised } \\
\text { layout }\end{array}$ & \\
\hline Aleppo & Syria & 2008-9 & $\begin{array}{l}\text { Warm } \\
\text { Mediterranean }\end{array}$ & $\begin{array}{l}\text { Light brown } \\
\text { chalky soil }\end{array}$ & $\begin{array}{l}201 \mathrm{~mm} \\
(2008), \\
263 \mathrm{~mm} \\
(2009)\end{array}$ & $\begin{array}{l}\text { Autumn-sown bread } \\
\text { wheat and winter-sown } \\
\text { lentils }\end{array}$ & $\begin{array}{l}\text { Triticum aestivum; Lens } \\
\text { culinaris }\end{array}$ & $\begin{array}{l}\text { Sheep manure, } \\
20 \text { and } 30 \\
\text { tonnes/ha on } \\
\text { wheat, } 10 \text { and } \\
20 \text { tonnes/ha } \\
\text { on lentils }\end{array}$ & $\begin{array}{l}\text { Four replicate } \\
\text { plots per } \\
\text { treatment, } \\
\text { randomised } \\
\text { layout }\end{array}$ & \\
\hline
\end{tabular}


Table 2

Summary of the farming study locations

\begin{tabular}{|c|c|c|c|c|c|c|}
\hline Region & $\begin{array}{l}\text { Climate } \\
\text { (Köppen- } \\
\text { Geiger) }\end{array}$ & Soil type(s) & $\begin{array}{l}\text { Annual } \\
\text { rainfall } \\
(\mathrm{mm})\end{array}$ & Cropping regime(s) & Crop(s) sampled & Manuring regime(s) \\
\hline $\begin{array}{l}\text { Lena district, } \\
\text { central Asturias, } \\
\text { Spain }\end{array}$ & $\begin{array}{l}\text { Temperate } \\
\text { oceanic }\end{array}$ & $\begin{array}{l}\text { range from light to } \\
\text { heavy (clay-rich) }\end{array}$ & $\begin{array}{l}\text { c. } 1000- \\
1100\end{array}$ & $\begin{array}{l}\text { Autumn/winter-sown spelt or } \\
\text { emmer/spelt maslin (sometimes with } \\
\text { peas or broad beans) usually rotated } \\
\text { with potatoes and/or maize, } \\
\text { occasionally with other garden crops; } \\
\text { rarely continuous spelt for several } \\
\text { years }\end{array}$ & $\begin{array}{l}\text { Triticum spelta; Triticum dicoccum; } \\
\text { Vicia faba; Pisum sativum }\end{array}$ & $\begin{array}{l}\text { Normally biennial, with cattle manure } \\
\text { applied to potatoes or maize in year } \\
\text { prior to sampling; occasionally direct } \\
\text { manuring of sampled spelt (otherwise } \\
\text { avoided due to problems of lodging); } \\
\text { occasionally no manure for several } \\
\text { years }\end{array}$ \\
\hline $\begin{array}{l}\text { Sighisoara } \\
\text { region, } \\
\text { Transylvania, } \\
\text { Romania }\end{array}$ & $\begin{array}{l}\text { Temperate } \\
\text { continental }\end{array}$ & $\begin{array}{l}\text { pale brown sandy } \\
\text { loam }\end{array}$ & c. 650 & $\begin{array}{l}\text { Autumn- and spring-sown einkorn, } \\
\text { spelt, barley, bread wheat, sometimes } \\
\text { with pulses (bitter vetch and lentil) }\end{array}$ & $\begin{array}{l}\text { Triticum monococcum; Triticum } \\
\text { aestivum; Lens culinaris }\end{array}$ & $\begin{array}{l}\text { Variable, ranging from no manure in } \\
\text { recent years to direct manuring of } \\
\text { cereals in the sampling year }\end{array}$ \\
\hline $\begin{array}{l}\text { Aliveri district, } \\
\text { central Evvia, } \\
\text { Greece }\end{array}$ & $\begin{array}{l}\text { Warm- } \\
\text { mediterranean }\end{array}$ & $\begin{array}{l}\text { red soil } \\
\text { [kokkinókhoma], } \\
\text { white soil } \\
\text { [asprókhoma], } \\
\text { brown soil } \\
\text { [melissókhoma], } \\
\text { 'dung soil' } \\
\text { [koprókhoma] }\end{array}$ & c. 430 & $\begin{array}{l}\text { Winter-sown pulses (mostly broad } \\
\text { bean) grown continuously or rotated } \\
\text { with summer vegetables, potatoes, } \\
\text { cereals (oats, barley) for hay }\end{array}$ & $\begin{array}{l}\text { Vicia faba; Pisum sativum; Lathyrus } \\
\text { ochrus (fava) }\end{array}$ & $\begin{array}{l}\text { Variable, ranging from intensive } \\
\text { annual manuring with sheep/goat } \\
\text { dung to intermittent manuring } \\
\text { (including by grazing or penned } \\
\text { sheep/goats) to no manuring in recent } \\
\text { years or decades }\end{array}$ \\
\hline
\end{tabular}


Table 3a

Results for the analysis of bulk samples from, Rothamsted, UK: A) Hoosfield Barley Experiment, and B) Broadbalk Winter Wheat Experiment (data from Bogaard et al., 2007 are included for comparison). Nil = unmanured; FYM2=35t/ha manure; FYMr- manured from 1852 until 1871 and unmanured thereafter; na = material not available for analysis (no replicate plots per treatment).

\begin{tabular}{|c|c|c|c|c|c|c|c|c|c|c|c|c|}
\hline \multirow[t]{3}{*}{ Year } & \multicolumn{6}{|c|}{$\delta^{15} \mathrm{~N}$} & \multicolumn{6}{|l|}{$\% \mathrm{~N}$} \\
\hline & \multicolumn{3}{|c|}{ Grain } & \multicolumn{3}{|c|}{ Rachis } & \multicolumn{3}{|c|}{ Grain } & \multicolumn{3}{|c|}{ Rachis } \\
\hline & Nil & FYM2 & FYMr & Nil & FYM2 & FYMr & Nil & FYM2 & FYMr & Nil & FYM2 & FYMr \\
\hline 1856 & 2.8 & 5.3 & na & na & na & na & 1.6 & 1.6 & na & na & na & na \\
\hline 1871 & 2.8 & 6.5 & na & na & na & na & 1.3 & 1.7 & na & na & na & na \\
\hline 1882 & 2.8 & 8.6 & 6.0 & $\begin{array}{l}1.5 \\
-\end{array}$ & 4.5 & 1.7 & 1.2 & 1.6 & 1.3 & 0.4 & 0.4 & 0.4 \\
\hline 1902 & 2.5 & 6.8 & 4.3 & 0.3 & 2.8 & 2.1 & 1.4 & 1.9 & 1.7 & 0.3 & 0.4 & 0.4 \\
\hline 1923 & 2.1 & 8.6 & 3.1 & na & na & 1.4 & 1.7 & 1.8 & 1.2 & na & na & 0.7 \\
\hline 1942 & 1.2 & 8.2 & 2.5 & 1.4 & 3.7 & 1.6 & 1.3 & 1.6 & 1.3 & 0.4 & 0.4 & 0.5 \\
\hline 1962 & 1.6 & 9.2 & 4.4 & 0.4 & 6.6 & 2.5 & 1.4 & 1.9 & 1.5 & 0.5 & 0.9 & 0.7 \\
\hline
\end{tabular}

B. Broadbalk Winter Bread wheat

\begin{tabular}{|c|c|c|c|c|c|c|c|c|}
\hline \multirow[t]{3}{*}{ Year } & \multicolumn{4}{|c|}{$\delta^{15} \mathrm{~N}$} & \multicolumn{4}{|l|}{$\% \mathrm{~N}$} \\
\hline & \multicolumn{2}{|c|}{ Grain } & \multicolumn{2}{|c|}{ Rachis } & \multicolumn{2}{|c|}{ Grain } & \multicolumn{2}{|c|}{ Rachis } \\
\hline & Nil & FYM2 & Nil & FYM2 & Nil & FYM2 & Nil & FYM2 \\
\hline 1852 & 2.7 & 5.8 & na & na & 1.8 & 2.0 & na & na \\
\hline 1895 & 2.9 & 7.8 & 0.6 & 5.0 & 1.9 & 1.8 & nd & nd \\
\hline 1935 & 4.0 & 8.3 & $\begin{array}{l}0.4 \\
-\end{array}$ & 7.1 & 1.8 & nd & 0.6 & 0.6 \\
\hline 1965 & 0.7 & 7.4 & 2.5 & 5.3 & 2.0 & 2.3 & 0.3 & 0.8 \\
\hline 1991 & 0.6 & 8.6 & $\begin{array}{l}\text { na } \\
-\end{array}$ & na & 1.5 & 2.0 & na & na \\
\hline 2004 & 0.8 & 6.6 & 2.6 & 3.4 & 1.5 & 1.9 & nd & nd \\
\hline
\end{tabular}


Table $3 b$

Results for the analysis of bulk samples from Askov, Denmark: Nil = unmanured plot; SLU $1 \frac{1}{2}=35 \mathrm{t} /$ ha manure slurry (average of three replicate plots per treatment, with $1 \mathrm{SD}$ in parentheses).

\begin{tabular}{|c|c|c|c|c|c|c|c|c|}
\hline \multirow[t]{3}{*}{ Year } & \multicolumn{8}{|c|}{$\delta^{15} \mathrm{~N}$} \\
\hline & \multicolumn{4}{|c|}{ Grain } & \multicolumn{4}{|c|}{ Rachis } \\
\hline & \multicolumn{2}{|l|}{ Nil } & \multicolumn{2}{|c|}{ SLU $1 \frac{1}{2}$} & \multicolumn{2}{|l|}{ Nil } & \multicolumn{2}{|c|}{ SLU $1 \frac{1}{2}$} \\
\hline \multicolumn{9}{|c|}{ Bread wheat } \\
\hline 2007 & -2.4 & $(0.6)$ & 8.1 & $(1.3)$ & -4.1 & $(0.6)$ & 5.3 & $(0.7)$ \\
\hline \multicolumn{9}{|c|}{ Hulled two-row barley } \\
\hline 2007 & -0.1 & $(0.6)$ & 8.7 & (1.9) & -2.1 & $(0.4)$ & 5.7 & (2.4) \\
\hline \multicolumn{9}{|c|}{ Emmer } \\
\hline 2008 & -0.6 & $(0.2)$ & 8.9 & $(0.6)$ & -2.1 & $(0.5)$ & 5.9 & $(0.4)$ \\
\hline \multicolumn{9}{|l|}{ Spelt } \\
\hline \multicolumn{9}{|c|}{ Naked two-row barley } \\
\hline 2008 & 0.2 & $(0.5)$ & 8.4 & $(1.3)$ & -2.2 & $(0.7)$ & 5.3 & $(1)$ \\
\hline \multirow[t]{3}{*}{ Year } & \multicolumn{8}{|l|}{$\% \mathrm{~N}$} \\
\hline & \multicolumn{4}{|c|}{ Grain } & \multicolumn{4}{|c|}{ Rachis } \\
\hline & \multicolumn{2}{|c|}{ Nil } & \multicolumn{2}{|c|}{ SLU $1 \frac{1}{2}$} & \multicolumn{2}{|c|}{ Nil } & \multicolumn{2}{|c|}{ SLU $1 \frac{1}{2}$} \\
\hline \multicolumn{9}{|c|}{ Bread wheat } \\
\hline 2007 & 1.2 & $(0.1)$ & 1.3 & $(0.1)$ & 0.2 & (0) & 0.2 & $(0)$ \\
\hline \multicolumn{9}{|c|}{ Hulled two-row barley } \\
\hline 2007 & 1.2 & (0) & 1.5 & $(0.1)$ & 0.3 & $(0.1)$ & 0.4 & $(0.2)$ \\
\hline $\begin{array}{l}\text { Emme } \\
2008\end{array}$ & 1.9 & (0) & 1.8 & $(0.1)$ & 0.2 & (0) & 0.2 & $(0)$ \\
\hline $\begin{array}{l}\text { Spelt } \\
2008\end{array}$ & 2.1 & $(0.1)$ & 2.1 & $(0.1)$ & 0.3 & $(0.1)$ & 0.3 & $(0)$ \\
\hline $\begin{array}{l}\text { Naked } \\
2008\end{array}$ & $\begin{array}{c}\text {-row } \\
1.8 \\
\end{array}$ & $\begin{array}{l}\text { rley } \\
(0.1)\end{array}$ & 1.8 & $(0.2)$ & 0.4 & (0) & 0.4 & (0) \\
\hline
\end{tabular}


Table 3c

Results for the analysis of bulk samples from Bad Lauchstädt, Germany: Nil = unmanured plot; FYM1 = 20t/ha manure; FYM2 = 35t/ha manure; na = material not available for analysis (no replicate plots per treatment).

\begin{tabular}{|c|c|c|c|c|c|c|c|c|c|c|c|c|}
\hline \multirow[t]{3}{*}{ Year } & \multicolumn{6}{|c|}{$\delta^{15} \mathrm{~N}$} & \multicolumn{6}{|l|}{$\% \mathrm{~N}$} \\
\hline & \multicolumn{3}{|c|}{ Grain or pulse } & \multicolumn{3}{|c|}{ Rachis } & \multicolumn{3}{|c|}{ Grain or pulse } & \multicolumn{3}{|c|}{ Rachis } \\
\hline & Nil & FYM1 & FYM2 & Nil & FYM1 & FYM2 & Nil & FYM1 & FYM2 & Nil & FYM1 & FYM2 \\
\hline \multicolumn{13}{|c|}{ Bread wheat } \\
\hline 2001 & 1.0 & 4.1 & 5.7 & na & na & na & 1.2 & 1.1 & 1.3 & na & na & na \\
\hline 2002 & 0.1 & 2.7 & 4.1 & na & na & na & 1.4 & 1.4 & 1.5 & na & na & na \\
\hline 2004 & 0.8 & 3.2 & 3.4 & -1.3 & 0.9 & 2.2 & 1.1 & 1.3 & 1.3 & 0.2 & 0.3 & 0.3 \\
\hline 2007 & 0.0 & 3.2 & 5.0 & -2.2 & 1.2 & 3.3 & 1.4 & 1.7 & 1.8 & 0.5 & 0.6 & 0.7 \\
\hline 2008 & 1.9 & 4.1 & 4.9 & 0.0 & 2.0 & 3.0 & 1.1 & 1.2 & 1.3 & 0.2 & 0.3 & 0.3 \\
\hline \multicolumn{13}{|c|}{ Hulled two-row barley } \\
\hline 2007 & -0.3 & 3.3 & 3.9 & -2.8 & 0.6 & 1.5 & 1.5 & 1.6 & 1.5 & 0.5 & 0.4 & 0.3 \\
\hline 2008 & -0.3 & 3.4 & 4.3 & -1.8 & 1.8 & 3.1 & 1.1 & 1.3 & 1.3 & 0.2 & 0.3 & 0.4 \\
\hline \multicolumn{13}{|l|}{ Pea } \\
\hline 2007 & -0.3 & 0.3 & 0.5 & & & & 3.4 & 3.7 & 3.7 & & & \\
\hline 2008 & 0.0 & 0.2 & 0.8 & & & & 3.0 & 3.0 & 3.0 & & & \\
\hline \multicolumn{13}{|c|}{ Broad bean } \\
\hline 2007 & -0.3 & 0.0 & 0.2 & & & & 4.2 & 5.1 & 4.6 & & & \\
\hline 2008 & -0.6 & -1.0 & 0.0 & & & & 4.1 & 4.3 & 3.7 & & & \\
\hline
\end{tabular}


Table 4a

Results for the analysis of bulk samples from Sutton Bonington, United Kingdom: Nil = unmanured plot; FYM 1 = 15-20t/ha manure; FYM $2=35 \mathrm{t} /$ ha manure; na= not available (average of three replicate plots per treatment, with 1 SD in parentheses).

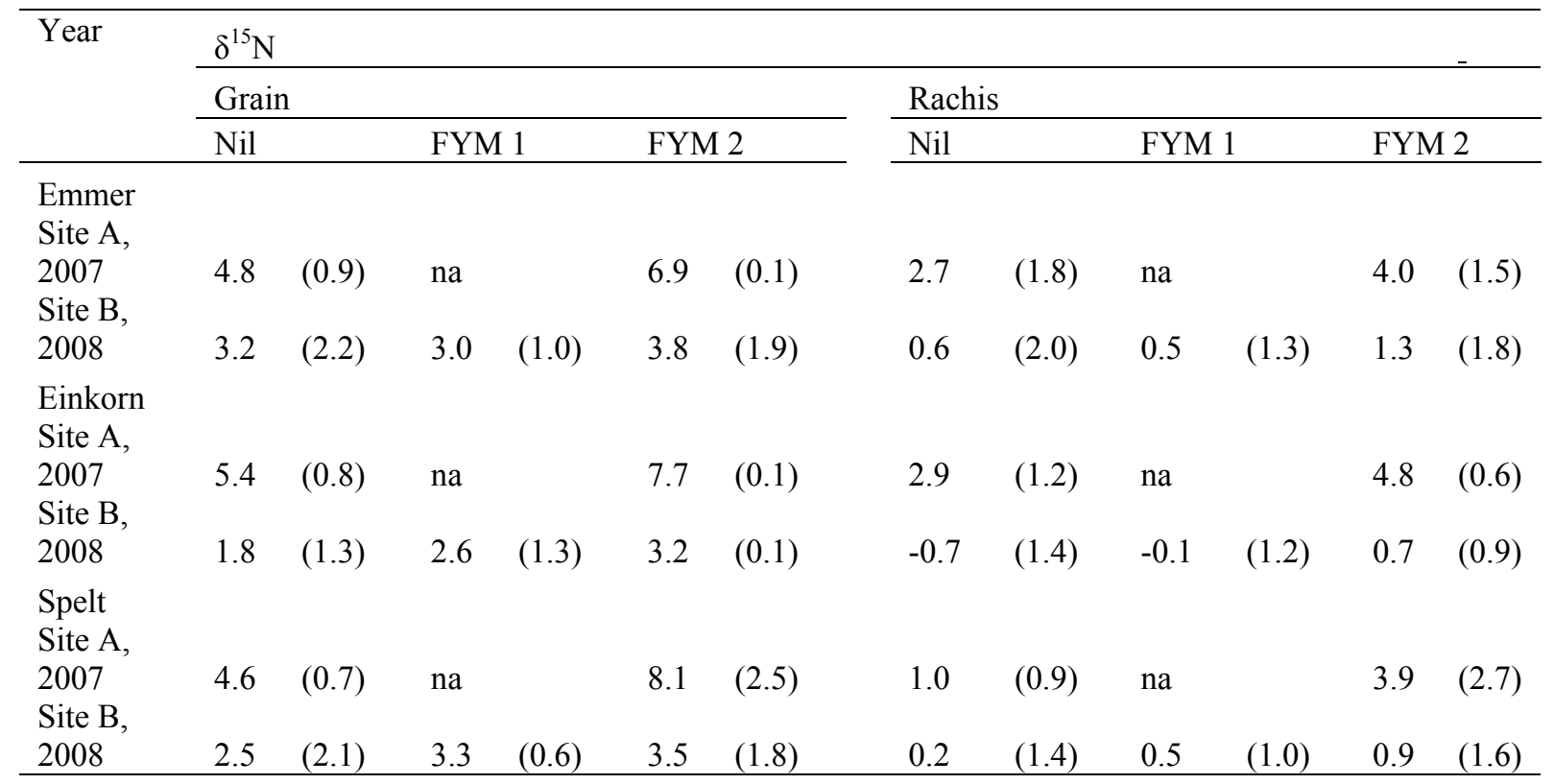

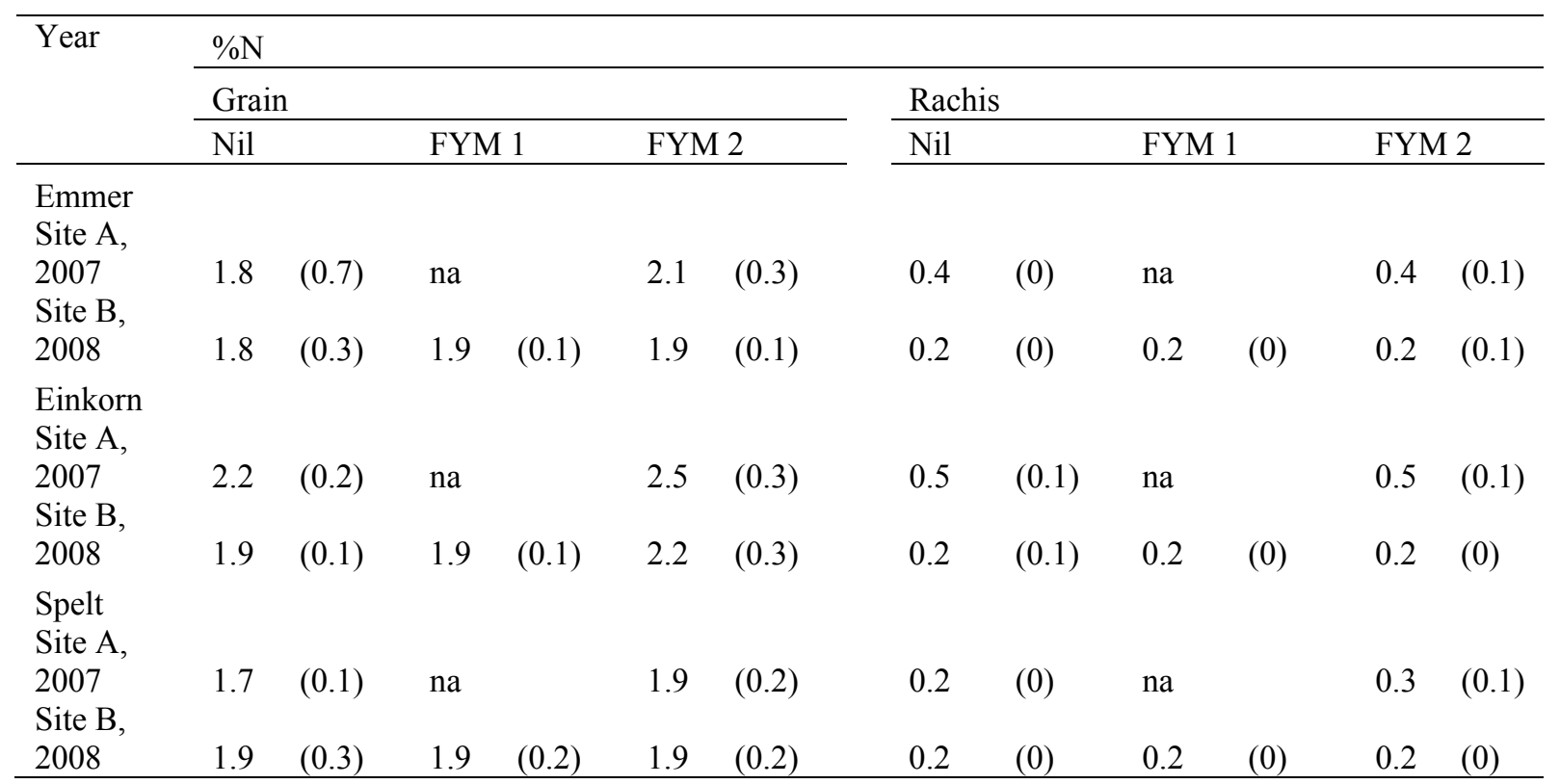


Table $4 b$

Results for the analysis of bulk samples from Aleppo, Syria: Nil-a = no manure/no irrigation, Nil-b = no manure/medium irrigation; Nil-c = no manure/full irrigation; FYM1-a = medium (20t/ha) manure/no irrigation; FYM1-b = medium (20t/ha) manure/medium irrigation; FYM1-c = medium $(20 t / h a)$ manure/full irrigation; FYM2 = high $(35 \mathrm{t} / \mathrm{ha})$ manure/full irrigation (average of three replicate plots per treatment, with 1 SD in parentheses).

\begin{tabular}{|c|c|c|c|c|c|c|c|c|c|c|c|c|c|c|}
\hline \multirow[t]{3}{*}{ Year } & \multicolumn{14}{|l|}{$\delta^{15} \mathrm{~N}$} \\
\hline & \multicolumn{14}{|c|}{ Grain } \\
\hline & \multicolumn{2}{|c|}{ Nil-a } & \multicolumn{2}{|c|}{ Nil- b } & \multicolumn{2}{|c|}{ Nil-c } & \multicolumn{2}{|c|}{ FYM 1- a } & \multicolumn{2}{|c|}{ FYM 1-b } & \multicolumn{2}{|c|}{ FYM 1- c } & \multicolumn{2}{|c|}{ FYM 2} \\
\hline \multicolumn{15}{|l|}{ Bread wheat } \\
\hline Site A, 2008 & -0.7 & $(0.2)$ & -0.5 & $(0.3)$ & 0.1 & $(0.4)$ & 1.4 & $(0.6)$ & 0.5 & $(0.6)$ & 0.9 & $(0.2)$ & 1.9 & $(0.4)$ \\
\hline $\begin{array}{l}\text { Site B, } 2009 \\
\text { Lentil }\end{array}$ & 0.6 & $(0.6)$ & 0.0 & $(0.5)$ & 1.3 & (1.1) & 4.5 & $(0.7)$ & 3.7 & $(0.4)$ & 6.0 & $(0.6)$ & 4.8 & $(0.7)$ \\
\hline Site A, 2008 & -0.6 & $(0.2)$ & 0.1 & $(0.4)$ & 0.1 & $(0.2)$ & 0.0 & $(0.3)$ & 0.0 & $(0.2)$ & 0.0 & $(0.5)$ & 0.4 & $(0)$ \\
\hline Site B, 2009 & -0.3 & $(0.3)$ & -0.5 & $(0.2)$ & -0.1 & $(0.2)$ & -0.3 & $(0.2)$ & 0.3 & $(0.4)$ & 0.3 & $(0.2)$ & 0.7 & $(0.4)$ \\
\hline \multirow[t]{3}{*}{ Year } & \multicolumn{14}{|l|}{$\delta^{15} \mathrm{~N}$} \\
\hline & \multicolumn{14}{|c|}{ Rachis } \\
\hline & \multicolumn{2}{|c|}{ Nil-a } & \multicolumn{2}{|c|}{ Nil- b } & \multicolumn{2}{|c|}{ Nil-c } & \multicolumn{2}{|c|}{ FYM 1- a } & \multicolumn{2}{|c|}{ FYM 1-b } & \multicolumn{2}{|c|}{ FYM 1- c } & \multicolumn{2}{|c|}{ FYM 2} \\
\hline \multicolumn{15}{|l|}{ Bread wheat } \\
\hline Site A, 2008 & -2.7 & $(0.4)$ & -2.6 & $(0.2)$ & -2.0 & $(0.9)$ & -1.1 & $(0.8)$ & -2.2 & $(0.9)$ & -1.3 & $(0.3)$ & -0.7 & $(0.5)$ \\
\hline Site B, 2009 & -0.5 & $(0.9)$ & -0.9 & $(0.4)$ & -0.7 & $(0.5)$ & 3.3 & $(0.9)$ & 3.3 & $(1.5)$ & 4.7 & $(2.3)$ & 3.5 & $(0.5)$ \\
\hline \multirow[t]{3}{*}{ Year } & \multicolumn{14}{|l|}{$\% \mathrm{~N}$} \\
\hline & \multicolumn{14}{|c|}{ Grain } \\
\hline & \multicolumn{2}{|c|}{ Nil-a } & \multicolumn{2}{|c|}{ Nil- b } & \multicolumn{2}{|c|}{ Nil-c } & FYM & $1-\mathrm{a}$ & FYN & $1-b$ & FYN & $1-c$ & FYM & \\
\hline Bread wheat & & & & & & & & & & & & & & \\
\hline Site A, 2008 & 1.3 & $(0.1)$ & 1.2 & $(0.2)$ & 1.8 & $(0.7)$ & 1.3 & $(0.1)$ & 1.4 & $(0.2)$ & 1.3 & $(0)$ & 1.4 & $(0.1)$ \\
\hline $\begin{array}{l}\text { Site B, } 2009 \\
\text { Lentil }\end{array}$ & 1.4 & $(0.1)$ & 1.4 & $(0.1)$ & 2.1 & $(0.7)$ & 1.4 & $(0)$ & 1.5 & $(0.2)$ & 1.4 & $(0.1)$ & 1.6 & $(0.1)$ \\
\hline Site A, 2008 & 4.0 & $(0.1)$ & 3.8 & $(0.2)$ & 4.1 & $(0.3)$ & 3.7 & $(0.2)$ & 4.0 & $(0.2)$ & 3.9 & $(0.1)$ & 3.9 & $(0.1)$ \\
\hline Site B, 2009 & 3.5 & $(0.1)$ & 3.8 & $(0.2)$ & 3.8 & $(0.5)$ & 3.6 & $(0.1)$ & 3.9 & $(0.2)$ & 3.6 & $(0.4)$ & 3.7 & $(0.1)$ \\
\hline Year & $\% \mathrm{~N}$ & & & & & & & & & & & & & \\
\hline & Rach & & & & & & & & & & & & & \\
\hline & Nil-a & & Nil- $\mathrm{b}$ & & Nil-c & & FYM & $1-\mathrm{a}$ & FYN & $1-b$ & FYN & $1-c$ & FYM & 2 \\
\hline Bread wheat & & & & & & & & & & & & & & \\
\hline Site A, 2008 & 0.3 & $(0.1)$ & 0.3 & $(0.1)$ & 0.3 & $(0)$ & 0.3 & $(0)$ & 0.3 & $(0)$ & 0.3 & (0) & 0.3 & $(0)$ \\
\hline Site B, 2009 & 0.2 & (0) & 0.3 & $(0)$ & 0.3 & $(0)$ & 0.4 & $(0.1)$ & 0.3 & $(0)$ & 0.3 & $(0)$ & 0.3 & $(0)$ \\
\hline
\end{tabular}




\section{Table 5a}

Results for the analysis of bulk samples from the Lena district, central Asturias, Spain: $\mathrm{Na}=$ material not available for analysis; $n d=$ not determined; Not Recent $=$ no recent manure applied; Biennial = manure applied every second year; Direct $=$ manure applied during sampled growing season (an average of 3 to 4 replicate fields were sampled per manure level when available, with $1 \mathrm{SD}$ in parentheses)

\begin{tabular}{|c|c|c|c|c|c|c|c|c|c|c|c|}
\hline \multirow{2}{*}{$\begin{array}{l}\text { Year } \\
2007\end{array}$} & Not recent & \multicolumn{2}{|c|}{ Biennial } & \multicolumn{2}{|c|}{ Direct } & Not & ent & \multicolumn{2}{|c|}{ Biennial } & \multicolumn{2}{|c|}{ Direct } \\
\hline & \multicolumn{5}{|c|}{ Grain or pulse $\delta^{15} \mathrm{~N}$} & \multicolumn{6}{|c|}{ Rachis $\delta^{15} \mathrm{~N}$} \\
\hline Spelt & $(2.5)$ & 3.9 & $(1.1)$ & 7.5 & $(2.3)$ & 2.3 & $(2.0)$ & 2.4 & $(1.0)$ & 5.2 & $(2.6)$ \\
\hline \multirow[t]{2}{*}{ Broad bean } & 1.0 & 0.6 & $(0.6$ & na & & & & & & & \\
\hline & Grain or pulse & $\% \mathrm{~N}$ & & & & $\mathrm{Rac}$ & $\% \mathrm{~N}$ & & & & \\
\hline Spelt & na & 2.2 & $(0.2)$ & na & & na & & 0.2 & $(0.0)$ & na & \\
\hline Broad bean & 4.1 & 3.5 & $(0.3)$ & & & & & & & & \\
\hline
\end{tabular}


Table $5 b$

Results for the analysis of bulk samples from the Sighisoara region, Transylvania, Romania: $\mathrm{na}=$ material not available for analysis; $\mathrm{nd}=$ not determined; Not recent $=$ no recent manure applied; Triennial $=$ manure applied every third year; Direct $=$ manure applied during sampled growing season (an average of 3 to 4 replicate fields were sampled per manure level when available, with $1 \mathrm{SD}$ in parentheses).

\begin{tabular}{|c|c|c|c|c|c|c|c|c|c|c|c|}
\hline \multirow{2}{*}{$\begin{array}{l}\text { Year } \\
2007\end{array}$} & Not recent & \multicolumn{2}{|c|}{ Triennial } & \multicolumn{2}{|c|}{ Direct } & \multirow{2}{*}{\multicolumn{2}{|c|}{$\begin{array}{l}\text { Not recent } \\
\text { Rachis } \delta^{15} \mathrm{~N}\end{array}$}} & \multicolumn{2}{|c|}{ Triennial } & \multicolumn{2}{|c|}{ Direct } \\
\hline & \multicolumn{5}{|c|}{ Grain or pulse $\delta^{15} \mathrm{~N}$} & & & & & & \\
\hline Bread wheat & $(1.2)$ & na & & 4.7 & $(0.9)$ & 0.1 & $(0.6)$ & na & & 1.9 & $(1.1)$ \\
\hline Einkorn & 1.4 & 2.7 & $(2.3)$ & 3.5 & (2) & -1.2 & & 1.0 & $(2.6)$ & 1.0 & (1.7) \\
\hline \multirow[t]{2}{*}{ Lentil } & 0.0 & 0.9 & & 0.5 & $(0.4)$ & & & & & & \\
\hline & \multicolumn{5}{|c|}{ Grain or pulse $\% \mathrm{~N}$} & \multicolumn{6}{|c|}{ Rachis \%N } \\
\hline Bread wheat & $(0.2)$ & na & & 1.7 & $(0.2)$ & 0.3 & $(0.0)$ & na & & 0.3 & $(0.0)$ \\
\hline Einkorn & 1.7 & 1.6 & & 2.0 & $(0.2)$ & 0.20 & & 0.2 & $(0.1)$ & 0.2 & $(0.0)$ \\
\hline Lentil & 4.9 & 3.8 & & 4 & $(0.4)$ & & & & & & \\
\hline
\end{tabular}


Table 5c

Results for the analysis of bulk samples from the Aliveri district of central Evvia, Greece: Low $=$ low manure, High $=$ high manure (an average of 3 to 4 replicate fields were sampled per manure level when available, with $1 \mathrm{SD}$ in parentheses).

\begin{tabular}{lllll}
\hline Year & Low & \multicolumn{3}{c}{ High } \\
\hline 2007 & $\delta^{15} \mathrm{~N}$ & & & \\
Broad bean & 0.6 & $(0.4)$ & 2.2 & $(1.4)$ \\
\hline & $\% \mathrm{~N}$ & & & \\
Broad bean & 4.1 & $(0.5)$ & 4.2 & $(0.4)$ \\
\hline
\end{tabular}


Table 6

Results of two-way ANOVA statistical tests (t-test applied to Rothamsted) on cereal grain and pulse, A) $\delta^{15} \mathrm{~N}$ values and, $\left.\mathrm{B}\right) \% \mathrm{~N}$ values $(\mathrm{F}(\mathrm{df}$ effect, $\mathrm{df}$ error $)=\mathrm{F}$ value, $\mathrm{p}$-value. $\dagger$ indicates data from all years were combined because sample sizes were too small for statistical analysis on separate years, na $=$ not applicable, ${ }^{*}$ significant response at an alpha level of 0.05).

A) Grain and pulse $\delta^{15} \mathrm{~N}$ values

\begin{tabular}{|c|c|c|c|c|}
\hline Site & $\begin{array}{l}\text { Effect of } \\
\text { manure }\end{array}$ & $p$ value & Effect of crop species & $\mathrm{p}$ value \\
\hline Rothamsted Broadbalk $\uparrow$ & $\mathrm{t}(7.49)$ & $<0.001 *$ & na & \\
\hline Rothamsted Hoosfield $\dagger$ & $\mathrm{t}(9.18)$ & $<0.001 *$ & na & \\
\hline Askov 2007 & $F(1,8)=195.34$ & $<0.001 *$ & $F(1,8)=4.48$ & 0.067 \\
\hline Askov 2008 & $\begin{array}{l}\mathrm{F}(1,12)= \\
319.54\end{array}$ & $<0.001 *$ & $\mathrm{~F}(2,12)=0.053$ & 0.949 \\
\hline $\begin{array}{l}\text { Sut. Bonington Site A } \\
2007\end{array}$ & $\mathrm{~F}(1,18)=24.37$ & $<0.001 *$ & $\mathrm{~F}(2,18)=0.54$ & 0.594 \\
\hline $\begin{array}{l}\text { Sut. Bonington Site B } \\
2008\end{array}$ & $\mathrm{~F}(2,27)=1.21$ & 0.313 & $\mathrm{~F}(2,27)=0.880$ & 0.426 \\
\hline Bad Lauchstädt cereals $\dagger$ & $\mathrm{F}(2,15)=57.41$ & $<0.001 *$ & $F(1,15)=2.71$ & 0.120 \\
\hline Bad Lauchstädt pulses $\uparrow$ & $\mathrm{F}(2,6)=4.23$ & 0.072 & $F(1,6)=8.55$ & $0.026^{*}$ \\
\hline Site and year & $\begin{array}{l}\text { Effect of } \\
\text { manure }\end{array}$ & $\mathrm{p}$ value & Effect of irrigation & $\mathrm{p}$ value \\
\hline $\begin{array}{l}\text { Aleppo Site A cereals } \\
2008\end{array}$ & $\mathrm{~F}(2,15)=18.01$ & $<0.001 *$ & $\mathrm{~F}(2,15)=1.30$ & 0.301 \\
\hline $\begin{array}{l}\text { Aleppo Site B cereals } \\
2009\end{array}$ & $F(2,15)=64.45$ & $<0.001^{*}$ & $\mathrm{~F}(2,15)=7.95$ & $0.004 *$ \\
\hline $\begin{array}{l}\text { Aleppo Site A pulses } \\
2008\end{array}$ & $\mathrm{~F}(2,15)=18.01$ & $<0.001 *$ & $\mathrm{~F}(2,15)=1.30$ & 0.301 \\
\hline $\begin{array}{l}\text { Aleppo Site B pulses } \\
2009\end{array}$ & $\mathrm{~F}(2,15)=7.41$ & $0.006^{*}$ & $\mathrm{~F}(2,15)=2.02$ & 0.167 \\
\hline
\end{tabular}

B) Grain and pulse $\% \mathrm{~N}$ values

\begin{tabular}{lllll}
\hline Site & $\begin{array}{l}\text { Effect of } \\
\text { manure }\end{array}$ & p value & Effect of crop species & $p$ value \\
\hline Rothamsted Broadbalk $\dagger$ & $\mathrm{t}(2.08)$ & 0.067 & na & \\
Rothamsted Hoosfield $\dagger$ & $\mathrm{t}(1.93)$ & 0.079 & na & \\
Askov 2007 & $\mathrm{F}(1,8)=15.33$ & $0.004^{*}$ & $\mathrm{~F}(1,8)=5.97$ & $0.040^{*}$ \\
Askov 2008 & $\mathrm{F}(1,12)=1.73$ & 0.213 & $\mathrm{~F}(2,12)=0.457$ & 0.644 \\
Sut. Bonington Site A & $\mathrm{F}(1,17)=3.12$ & 0.095 & $\mathrm{~F}(2,17)=14.56$ & $<0.001$ \\
$\begin{array}{l}\text { 2007 } \\
\text { Sut. Bonington Site B }\end{array}$ & $\mathrm{F}(2,27)=0.99$ & 0.386 & $\mathrm{~F}(2,27)=1.09$ & 0.351 \\
$\begin{array}{l}\text { 2008 } \\
\text { Bad Lauchstädt cereals } \dagger\end{array}$ & $\mathrm{F}(2,15)=0.86$ & 0.442 & $\mathrm{~F}(1,15)=0.19$ & 0.670 \\
Bad Lauchstädt pulses $\dagger$ & $\mathrm{F}(2,6)=0.63$ & 0.566 & $\mathrm{~F}(2.6)=14.785$ & $0.009^{*}$ \\
\hline
\end{tabular}




\begin{tabular}{|c|c|c|c|c|}
\hline Site and year & $\begin{array}{l}\text { Effect of } \\
\text { manure }\end{array}$ & $\mathrm{p}$ value & Effect of irrigation & $\mathrm{p}$ value \\
\hline $\begin{array}{l}\text { Aleppo Site A cereals } \\
2008\end{array}$ & $\mathrm{~F}(2,15)=0.97$ & 0.401 & $F(2,15)=3.49$ & 0.057 \\
\hline $\begin{array}{l}\text { Aleppo Site B cereals } \\
2009\end{array}$ & $\mathrm{~F}(2,15)=3.05$ & 0.078 & $F(2,15)=3.83$ & $0.05 *$ \\
\hline $\begin{array}{l}\text { Aleppo Site A pulses } \\
2008\end{array}$ & $\mathrm{~F}(2,15)=0.97$ & 0.401 & $F(2,15)=3.50$ & 0.057 \\
\hline $\begin{array}{l}\text { Aleppo Site B pulses } \\
2009\end{array}$ & $\mathrm{~F}(1,15)=0.24$ & 0.792 & $F(2,15)=1.50$ & 0.261 \\
\hline
\end{tabular}


Table 7

Results of two-way ANOVA tests (t-test applied to Rothamsted) on cereal rachis, A) $\delta^{15} \mathrm{~N}$ values and, $\mathrm{B}) \% \mathrm{~N}$ values $(\mathrm{F}(\mathrm{df}$ effect, $\mathrm{df}$ error $)=\mathrm{F}$ value, $\mathrm{p}$-value. $\dagger$ indicates data from all years were combined because sample sizes were too small for statistical analysis on separate years, na $=$ not applicable, ${ }^{*}$ significant response at an alpha level of 0.05 ).

A) Cereal rachis $\delta^{15} \mathrm{~N}$

\begin{tabular}{|c|c|c|c|c|}
\hline Site and year & Effect of manure & $\mathrm{p}$ value & Effect of crop species & $\mathrm{p}$ value \\
\hline Rothamsted Broadbalk & $\dagger \dagger$ & & na & \\
\hline Rothamsted Hoosfield $\uparrow$ & $\mathrm{t}(6.13)$ & $0.001^{*}$ & na & \\
\hline Askov 2007 & $F(1,6)=197.37$ & $<0.001 *$ & $F(1,6)=1.92$ & 0.209 \\
\hline Askov 2008 & $F(1,12)=321.97$ & $<0.001 *$ & $F(2,12)=0.68$ & 0.527 \\
\hline $\begin{array}{l}\text { Sut. Bonington Site A } \\
2007\end{array}$ & $F(1,18)=10.09$ & $0.005^{*}$ & $F(2,18)=1.63$ & 0.223 \\
\hline $\begin{array}{l}\text { Sut. Bonington Site B } \\
2008\end{array}$ & $\mathrm{~F}(2,26)=1.31$ & 0.287 & $F(2,26)=1.02$ & 0.375 \\
\hline Bad Lauchstädt $\dagger$ & $\mathrm{F}(2,9)=34.3$ & $<0.001 *$ & $\mathrm{~F}(2,9)=1.9$ & 0.192 \\
\hline Site and year & Effect of manure & $\mathrm{p}$ value & Effect of irrigation & $\mathrm{p}$ value \\
\hline Aleppo Site A 2008 & $F(2,15)=3.28$ & 0.066 & $\mathrm{~F}(2,15)=0.97$ & 0.403 \\
\hline Aleppo Site B 2009 & $F(2,15)=31.47$ & $<0.001 *$ & $\mathrm{~F}(2,15)=0.91$ & 0.422 \\
\hline
\end{tabular}

B) Cereal rachis $\% \mathrm{~N}$

\begin{tabular}{lllll}
\hline Site and year & Effect of manure & $\mathrm{p}$ value & Effect of crop species & $\mathrm{p}$ value \\
\hline Rothamsted Broadbalk & $\dagger \dagger$ & & na & \\
Rothamsted Hoosfield $\dagger$ & $\mathrm{t}(0.95)$ & 0.380 & na & \\
Askov 2007 & $\mathrm{F}(1,7)=0.801$ & 0.405 & $\mathrm{~F}(1,7)=2.96$ & 0.136 \\
$\begin{array}{l}\text { Askov 2008 } \\
\text { Sut. Bonington Site A }\end{array}$ & $\mathrm{F}(1,12)=0.19$ & 0.671 & $\mathrm{~F}(1,12)=17.96$ & $<0.001^{*}$ \\
$\begin{array}{l}\text { 2007 } \\
\text { Sut. Bonington Site B }\end{array}$ & $\mathrm{F}(2,27)=0.17$ & 0.057 & $\mathrm{~F}(2,17)=19.44$ & $<0.001^{*}$ \\
$\begin{array}{l}\text { 2008 } \\
\text { Bad Lauchstädt } \dagger\end{array}$ & $\mathrm{F}(2,9)=0.19$ & 0.834 & $\mathrm{~F}(2,27)=2.78$ & 0.080 \\
\hline Site and year & $\mathrm{Effect}$ of manure & $\mathrm{p}$ value & $\mathrm{Fffect}$ of irrigation & $\mathrm{p}$ value \\
\hline $\begin{array}{l}\text { Aleppo Site A 2008 } \\
\text { Aleppo Site B 2009 }\end{array}$ & $\mathrm{F}(1,12)=0.05$ & 0.956 & $\mathrm{~F}(1,12)=0.39$ & 0.678 \\
\hline
\end{tabular}


Figure 1

Map showing location of sites: 1) Sutton Bonington, 2) Rothamsted, 3) Askov, 4) Bad Lauchstädt, 5) Asturias, 6) Sighisoara, 7) Evvia and 8) Aleppo.

Figure 2

$\delta^{15} \mathrm{~N}$ values for bulk samples of grain from the long-term experimental plots at: a) Rothamsted (no replicates per plot), b) Askov (average of 3 replicates per plot with 1 SD), c) Bad Lauchstädt (no replicates per plot).

Figure 3

$\delta^{15} \mathrm{~N}$ values for bulk samples of grain from the short-term experimental plots at: a) Sutton Bonington: SB-Site A, 2007, b) Sutton Bonington: SB-Site B, 2008, b) Aleppo: ALSite A, 2008, c) Aleppo: AL-Site B, 2009. Average of 3 replicate plots per treatment, with $1 \mathrm{SD}$.

Figure 4

$\delta^{15} \mathrm{~N}$ values for bulk samples of pulses from, a) long-term experimental plots at Bad Lauchstädt (no replicates per plot), and b) short-term experimental plots at Aleppo (average of three replicate plots per treatment, with 1 SD).

Figure 5

The $\delta^{15} \mathrm{~N}$ values for bulk samples of grain and pulses from the traditional farming studies at: a) Asturias, b) Sighisoara, c) Evvia. No replicates per field at each site.

Figure 6 
The relationship between $\delta^{15} \mathrm{~N}$ values of cereal grain and rachis. The $\mathrm{r}$ value reports the Pearson product-moment correlation coefficient and P value, at a significance level of 0.05 .

\section{Figure 7}

The relationships between a) unmanured and b) FYM 2 and SLU 11/2 (Askov) manured cereal $\delta^{15} \mathrm{~N}$ values and mean annual precipitation. The $\mathrm{r}$ values report the Pearson product-moment correlation coefficients and P values, at a significance level of 0.05 . 
Figure 1- Map showing location of sites

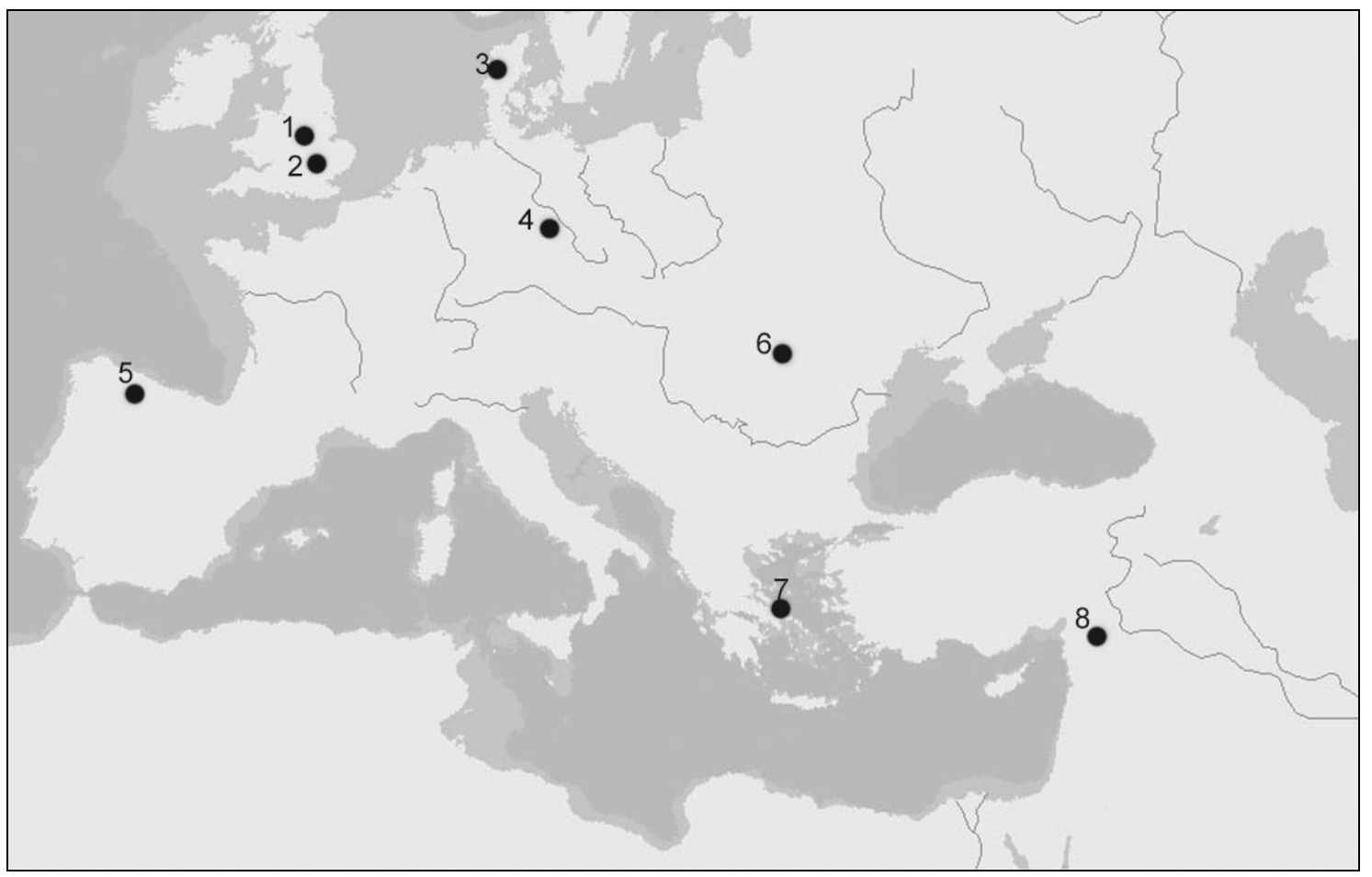

1. Sutton Bonington

2. Rothamsted

3. Askov

4. Bad Lauchstädt

5. Asturias

6. Sighisoara

7. Evvia

8. Aleppo 
Figure 2

$\delta^{15} \mathrm{~N}$ values for bulk samples of grain from the long-term experimental plots at: a) Rothamsted (no replicates per plot), b) Askov (average of 3 replicates per plot with 1 SD), c) Bad Lauchstädt (no replicates per plot).

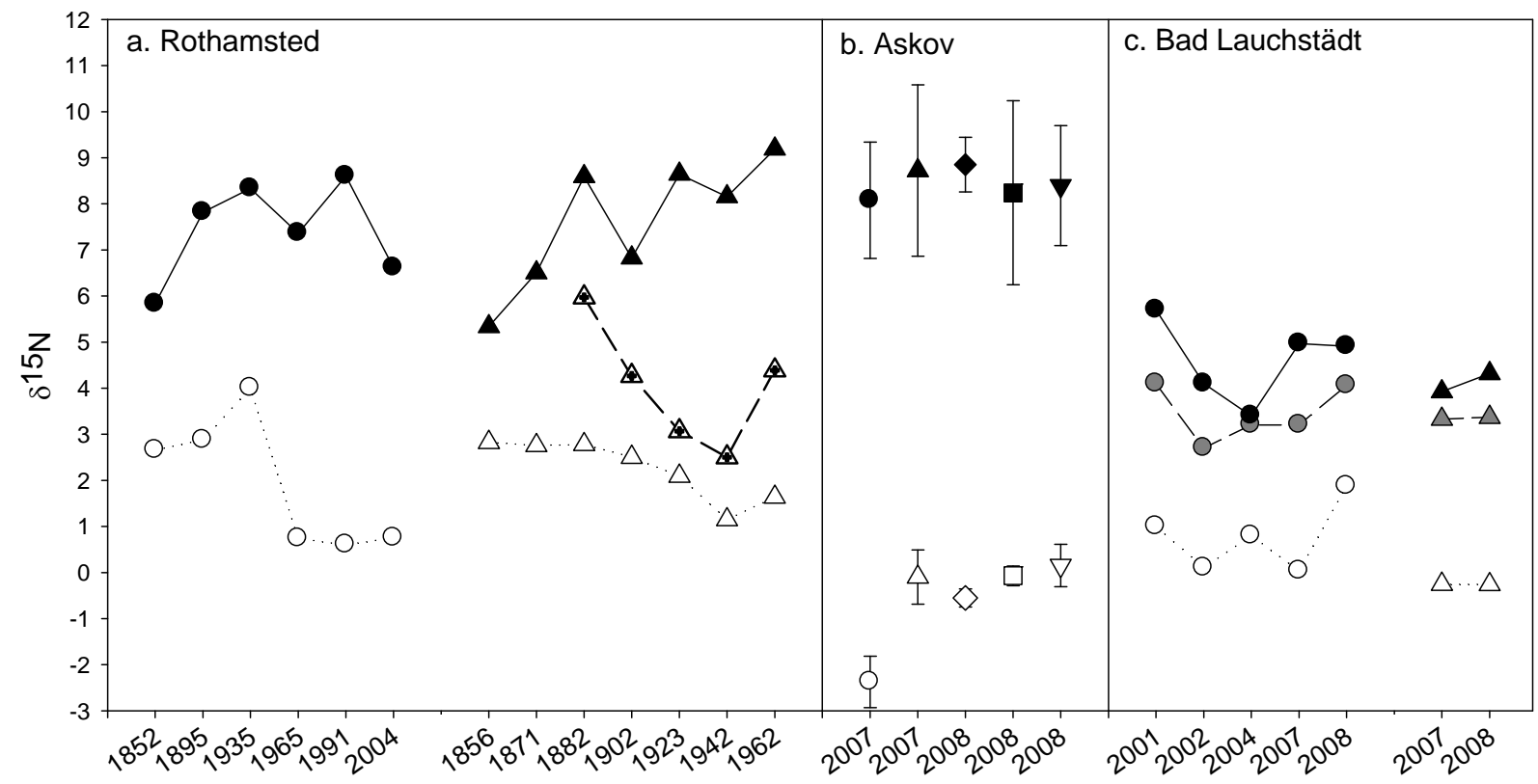

unmanured bread wheat

$\triangle$ unmanured hulled barley

$\diamond$ unmanured emmer

$\square \quad$ unmanured spelt

$\nabla \quad$ unmanured naked barley

- FYM 1 bread wheat

$\triangle \quad$ FYM 1 hulled barley

- FYM 2 (Askov SLU 11/2) bread wheat

- FYM 2 (Askov SLU 11/2) hulled barley

- FYM 2 (Askov SLU 11/2) emmer

- FYM 2 (Askov SLU 11/2) spelt

V FYM 2 (Askov SLU 11/2) naked barley

$\Delta \quad$ FYMr hulled barley - manuring ceased 1871 
Figure 3

$\delta^{15} \mathrm{~N}$ values for bulk samples of grain from the short-term experimental plots at: a) Sutton Bonington: SB-Site A, 2007, b) Sutton Bonington: SB-Site B, 2008, b) Aleppo: AL-Site A, 2008, c) Aleppo: AL-Site B, 2009. Average of 3 replicate plots per treatment, with 1 SD.

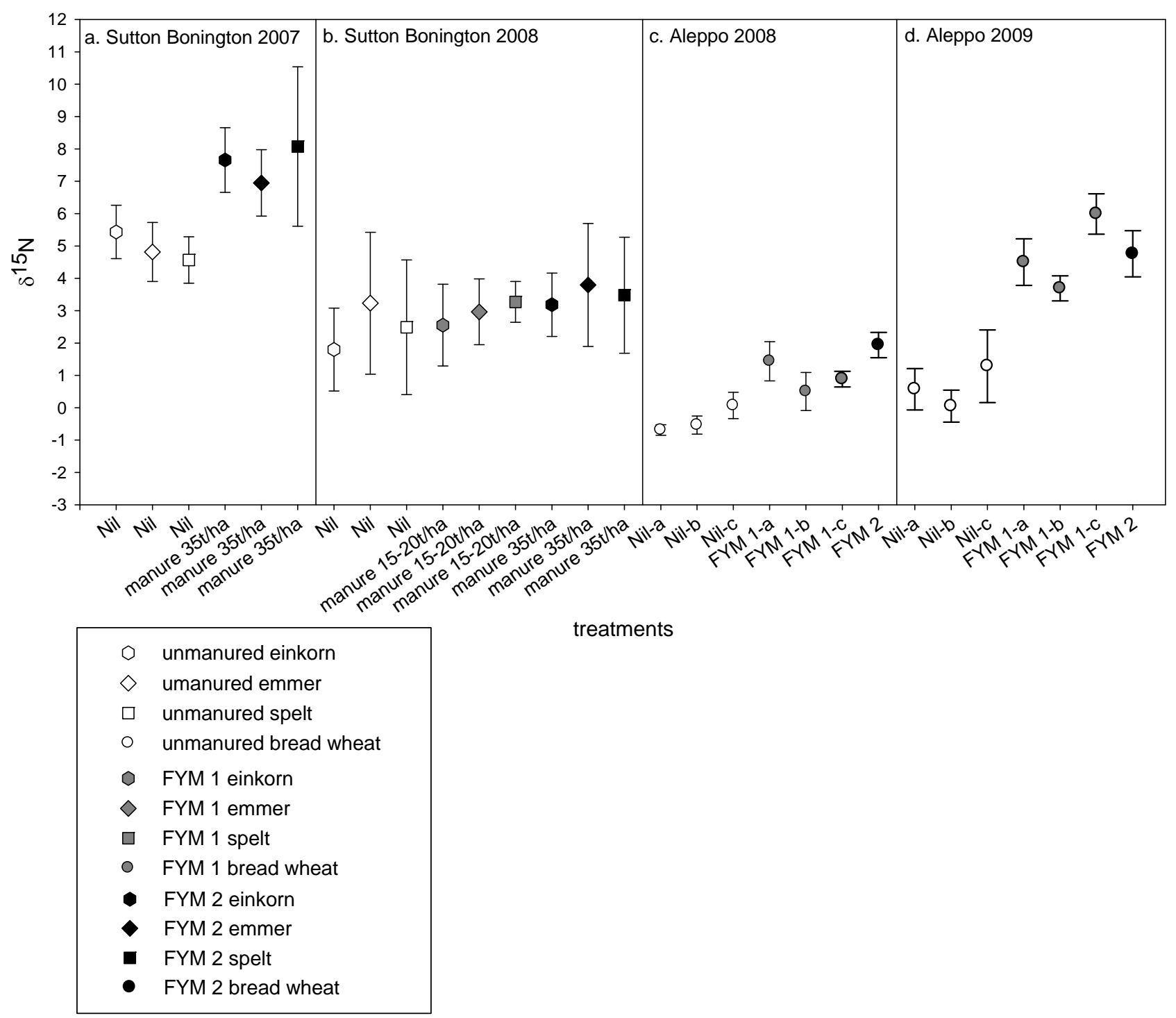


Figure 4

$\delta^{15} \mathrm{~N}$ values for bulk samples of pulses from, a) long-term experimental plots at Bad Lauchstädt (no replicates per plot), and b) short-term experimental plots at Aleppo (average of three replicate plots per treatment, with 1 SD).

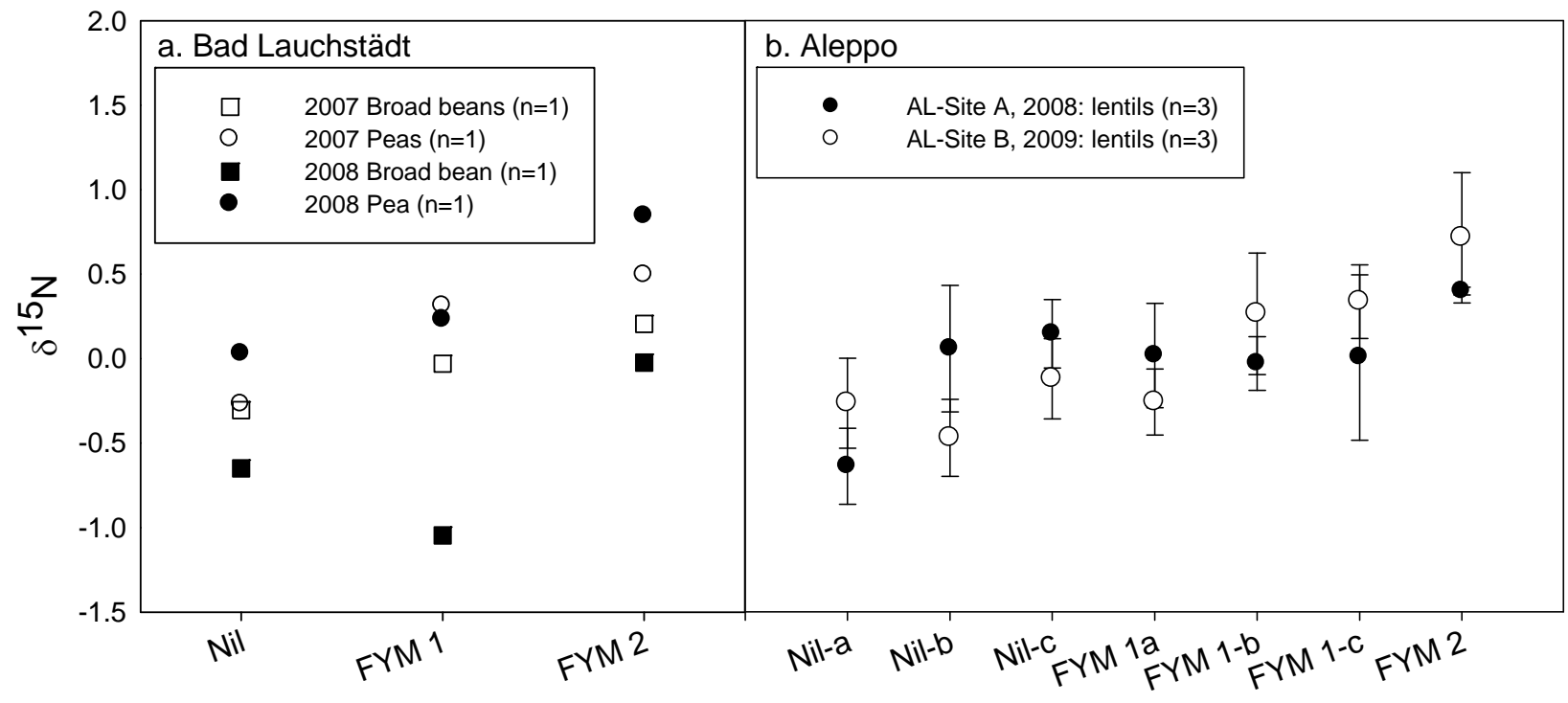

treatments 
Figure 5

The $\delta^{15} \mathrm{~N}$ values for bulk samples of grain and pulses from the traditional farming studies at: a) Asturias, b) Sighisoara, c) Evvia. No replicates per field at each site.

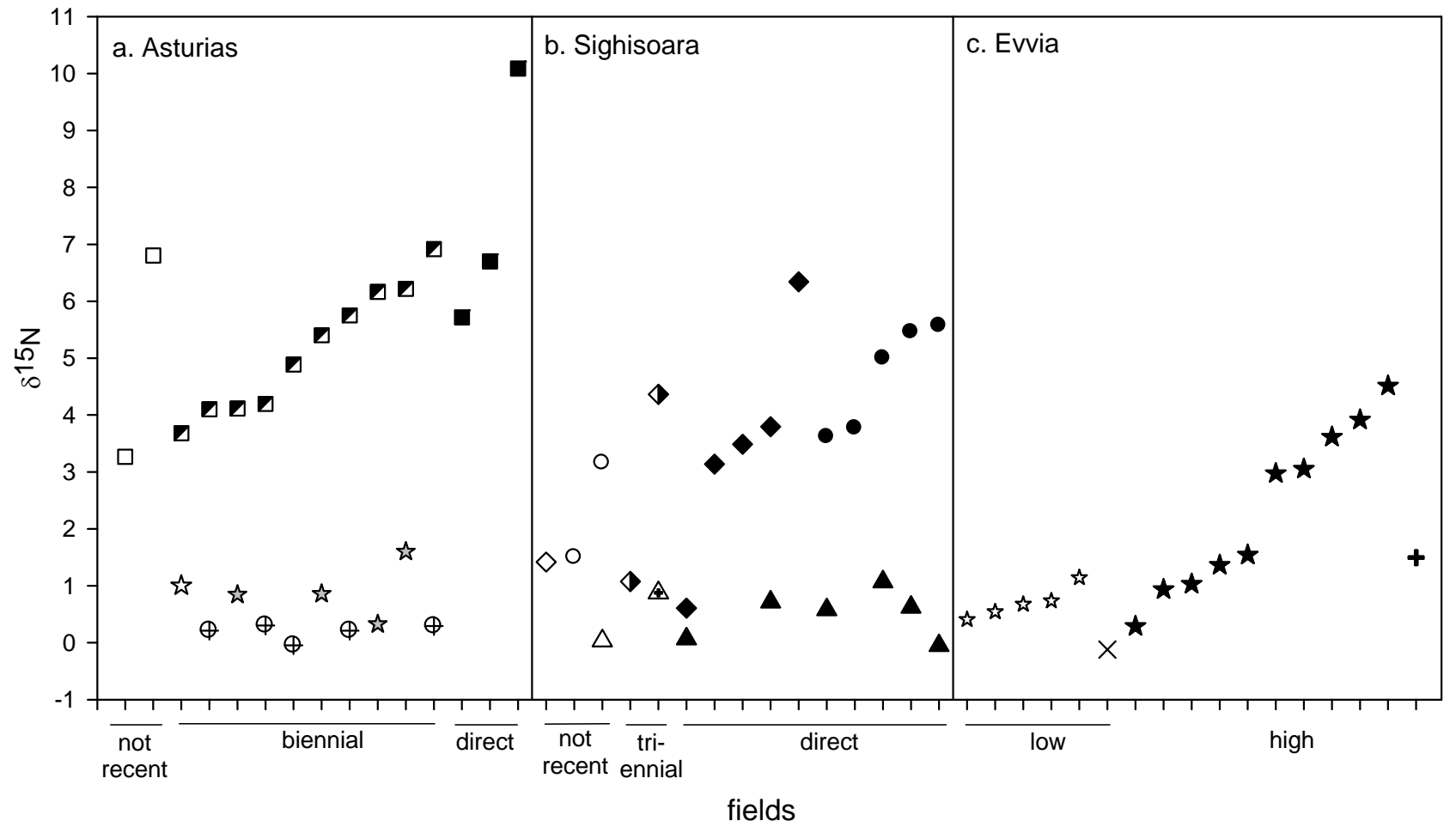

\begin{tabular}{|ll|}
\hline$\square$ & spelt- not recent \\
$\square$ & spelt- biennial \\
$\square$ & spelt- direct \\
$\diamond$ & einkorn- not recent \\
$\triangleleft$ & einkorn- triennial \\
$\bullet$ & einkorn- direct \\
0 & bread wheat- not recent \\
$\bullet$ & bread wheat- direct \\
$\star$ & broad bean- not recent/low \\
$\star$ & broad bean- biennial \\
$\star$ & broad bean- direct/high \\
$\oplus$ & pea- biennial \\
$\Delta$ & lentil- not recent \\
$\Delta$ & lentil- triennial \\
$\Delta$ & lentil- direct \\
$\times$ & fava- low \\
$\boldsymbol{\Delta}$ & fava- high \\
\hline
\end{tabular}


Figure 6

The relationship between $\delta^{15} \mathrm{~N}$ values of cereal grain and rachis. The $r$ value reports the Pearson product-moment correlation coefficient and $\mathrm{P}$ value, at a significance level of 0.05 .

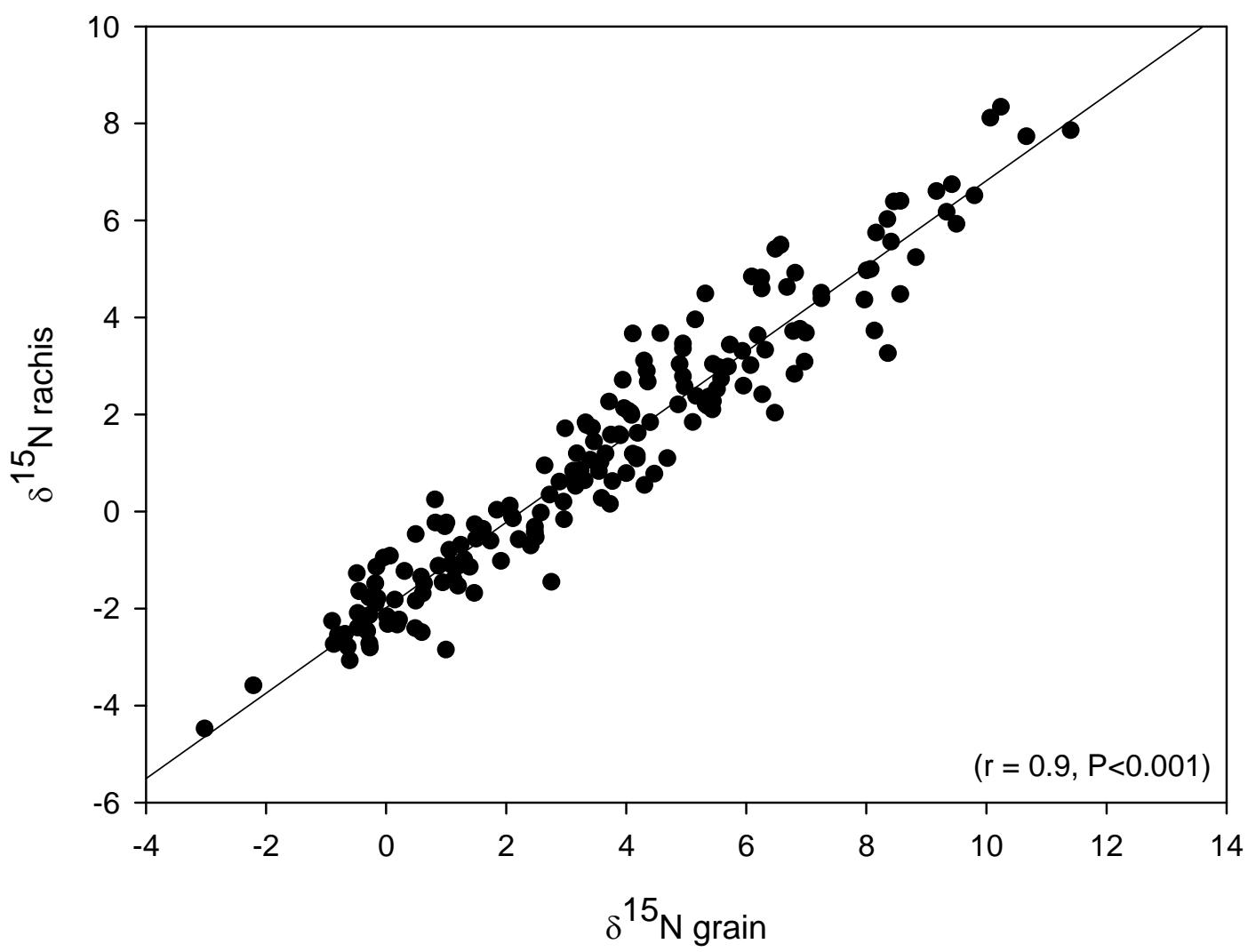


Figure 7

The relationships between a) unmanured and b) FYM 2 and SLU 11/2 (Askov) manured cereal $\delta^{15} \mathrm{~N}$ values and mean annual precipitation. The $r$ values report the Pearson product-moment correlation coefficients and $\mathrm{P}$ values, at a significance level of 0.05 .
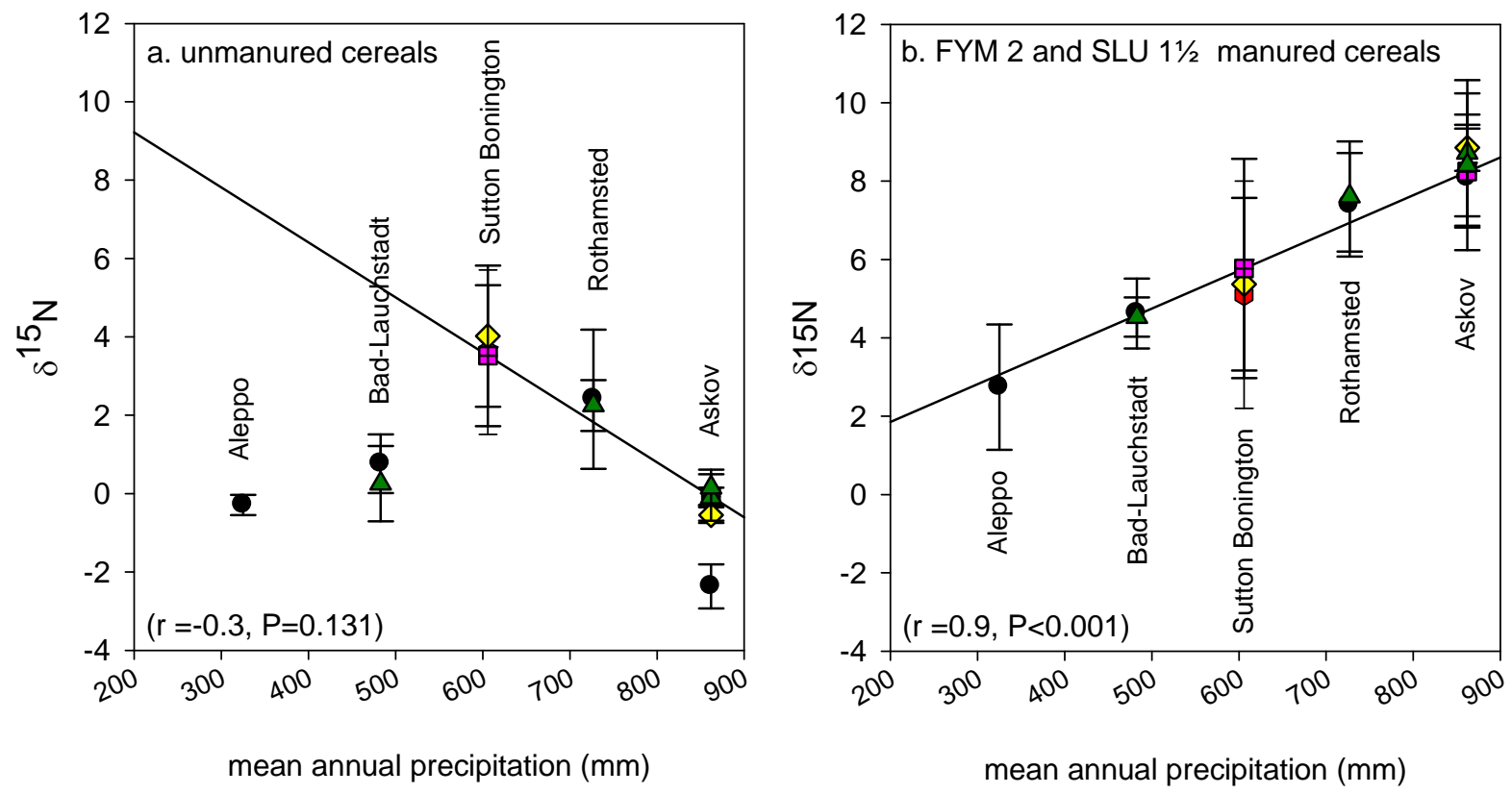

\begin{tabular}{|ll|}
\hline$\diamond$ & einkorn \\
$\diamond$ & emmer \\
$\bullet$ & bread wheat \\
⿴囗十 & spelt \\
$\Delta$ & barley \\
\hline
\end{tabular}

